\title{
Assessment of impacts from human activities on ecosystem components in the Bay of Biscay in the early 1990s
}

\author{
Pascal Lorance ${ }^{1, a}$, Jacques A. Bertrand, Anik Brind'Amour ${ }^{1}$, Marie-Joëlle Rochet ${ }^{1}$ and Verena M. Trenkel ${ }^{1}$ \\ Ifremer, Département EMH, BP 21105, 44311 Nantes Cedex, France
}

Received 3 February 2009; Accepted 14 September 2009

\begin{abstract}
The ecosystem-based approach to fisheries management and, more specifically, the European Marine Strategy Framework Directive require the assessment of the state and dynamics of an ecosystem in order to determine suitable management strategies. This paper takes an analytical approach to assess the state of the Bay of Biscay ecosystem in the early 1990s, chosen as a period of reference because key monitoring data series have been collected since then. To assess the state of the ecosystem, the pressures exerted by six broad categories of human activities were examined. A literature review of the ecosystem components was made and a component tree was tailored according to data availability. Data rich components were subdivided into subcomponents for their assessment while data poor components were assessed at an aggregated level. The component tree of the ecosystem comprised six main branches, four of which further divided into sub-components. In total, assessments were carried out at the level of 19 components. For four of these (fished species, sensitive fish species, marine mammals and turtles) the overall assessments were made combining the status of individual species. Impact from human activities were categorised as (i) "widespread" over the whole Bay of Biscay or "local" and (ii) "possible" when they could be logically expected or "documented" when they were reported in the literature. Fishing appeared to be the only activity exerting widespread documented impacts on several ecosystem components. Terrestrial activities had some possible and documented widespread impacts. With the exception of marine transport impacting seabirds at the regional scale through oil pollution, other activities had only local impacts, mostly nearshore. The reference state in the early 1990s, suggests that continuation of monitoring of vertebrates as well as estuarine and coastal habitats must be central to the monitoring programme and management strategies to be set in the context of the Marine Strategy Framework Directive. Additional monitoring is also required for benthos, substrate and micro-organisms.
\end{abstract}

Key words: Reference state / Ecosystem-based management / Human pressure / Inventory / Atlantic Ocean

Résumé - L'approche écosystémique de la gestion des pêches et, plus récemment, la Directive-cadre de l'Union Européenne «Stratégie pour le milieu marin », requièrent l'évaluation de l'état et de la dynamique d'un écosystème afin de définir des stratégies de gestion adéquate. Cet article adopte une approche analytique pour évaluer l'état de l'écosystème du golfe de Gascogne au début des années 1990, période de référence choisie parce que des séries temporelles de données de surveillance existent depuis lors. Pour évaluer l'état de l'écosystème au début des années 1990, les pressions exercées par six grandes catégories d'activités humaines ont été examinées. Une revue bibliographique des composantes de l'écosystème est faite et un arbre des composantes est défini selon les données disponibles. Les composantes riches en données sont subdivisées en sous-composantes, tandis que les composantes moins bien connues sont évaluées à un niveau agrégé. L'arbre des composantes comprend six branches principales dont quatre sont divisées en sous-composantes de sorte que les évaluations sont faites au niveau de 19 composantes. Pour quatre composantes (espèces exploitées par la pêche, espèce de poissons sensibles, mammifères marins et tortues) les évaluations d'ensemble résultent de combinaisons de l'état des espèces prises individuellement. Les effets des activités humaines sont classés comme (i) «étendus » à tout le golfe de Gascogne ou «localisés » et (ii) «possibles » quand ces impacts devraient logiquement avoir un effet sur une composante de l'écosystème ou «documentés » quand ils sont rapportés dans la littérature. La pêche ressort comme la seule activité ayant eu un impact étendu et documenté sur plusieurs composantes de l'écosystème au début des années 1990. Les activités humaines continentales ont des impacts, étendus, documentés ou possibles sur quelques composantes. A l'exception des transports maritimes qui ont un impact probable sur les oiseaux marins à l'échelle régionale, dû à la pollution par les hydrocarbures, les autres activités n'ont que des impacts locaux, essentiellement près de la côte. L'évaluation des composantes implique que la poursuite du suivi des vertébrés

\footnotetext{
a Corresponding author: pascal. lorance@ifremer.fr
} 
Suite du texte du résumé.et des habitats estuariens et côtiers devra être au centre de la surveillance et de la gestion à développer pour la Directive-cadre Stratégie pour le milieu-marin. De plus, le benthos, les fonds marins et les microorganismes devraient aussi être intégrés à cette surveillance.

\section{Introduction}

The ecosystem-based approach to fisheries management requires the appraisal of the state of an ecosystem to determine suitable management strategies. In European waters, the implementation of the European Marine Strategy Framework Directive (MSFD) has made it mandatory to produce an initial assessment of the current environmental status in all marine regions under the jurisdiction of Member States by 15 July 2012 (European Union 2008). To achieve this, the MSFD provides a definition of a "good environmental status" and requires Member States to "... establish a comprehensive set of environmental targets and associated indicators for their marine waters ..." for environmental monitoring after the initial assessment. The assessment and progress towards the good environmental status of marine waters targeted by the MSFD implies the integration of ecological and human activity indicators into a comprehensive framework. According to the pressure-state-response (PSR) framework of the Organisation for Economic Co-operation and Development (OECD), human activities exert "pressure" on the environment, changing the "state", - e.g. the quality or quantity - of natural resources (Singh et al. 2009). Pressures can be direct or indirect. For example, fishing exerts a direct pressure on targeted and bycatch fish as well as on the benthos. It also exerts indirect pressure on some populations or on the whole community through its consequences on the food web or degradation of the habitats.

Ecosystems are multidimensional, and the multidisciplinary knowledge collected is often consolidated only after some time. Identifying and describing systematically all the ecosystem components is a prerequisite to avoid information bias caused by disregarding ecosystem components that might not have been studied or explicitly identified, since the inclusion of poorly known components allows to refer to them in terms of uncertainty and may also help to identify data collection needs in the context of the MSFD. A temporal perspective is required, as changes in environmental factors and human pressures will have delayed effects, e.g. because of the lifespan of individuals affected and the time required by the transfer of an impact through ecological compartments. In addition to these "natural" delays, the investigation, reporting and validation of these effects also implies delays, possibly long ones. For example, the reporting of marine species extinction may lag several decades behind the actual extinction time (Dulvy et al. 2005).

As a first step towards an ecosystem assessment, we describe here the components of the Bay of Biscay ecosystem and the human activities pressuring them. The Bay of Biscay is a mid-latitude shelf ecosystem in the North East Atlantic. The study area is restricted to the Eastern Bay of Biscay shelf, corresponding to Divisions VIIIa-b of the International Council for the Exploration of the Sea (ICES) (Fig. 1). For simplicity, we will refer to it as the Bay of Biscay, although this term normally includes the Cantabrian Sea (ICES Division VIIIc) and the deep offshore basin (ICES Division VIIId). In this area,

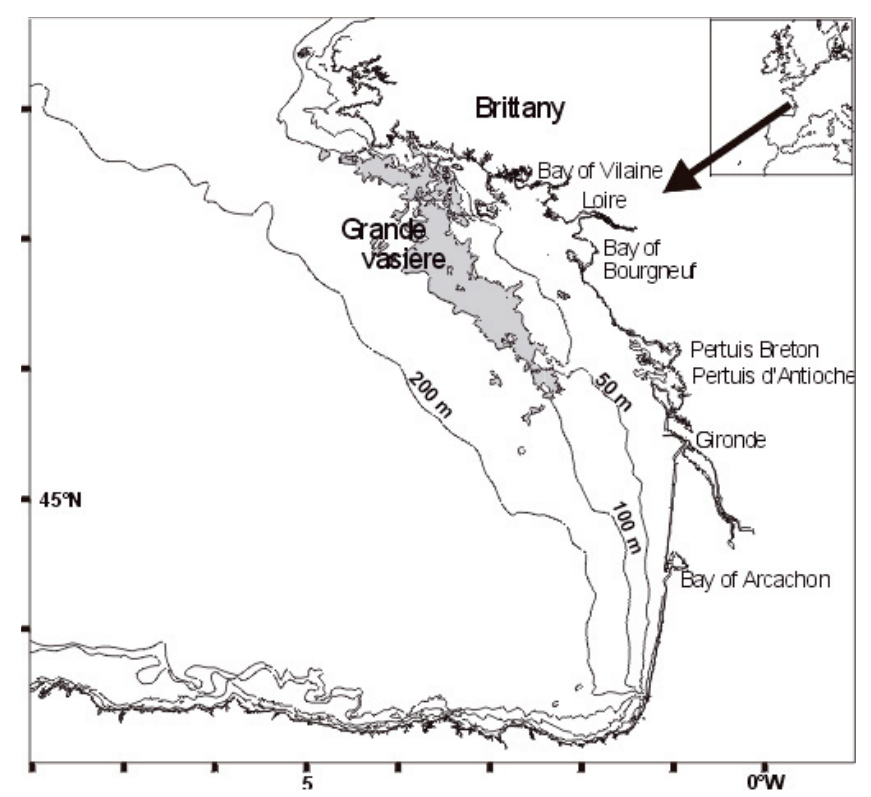

Fig. 1. Chart of the mud shelf deposit (Grande Vasière), main estuaries and semi-enclosed bays (from Bourillet et al. 2006).

coastal environmental monitoring dates back to the late 1970 s (Beliaeff et al. 2005), and systematic monitoring of the benthic and demersal fish community started in the early 1990s with the institution of an annual bottom trawl survey. Therefore, we selected the early 1990s as the reference time for establishing the baselines because it is sufficiently far back in time to offer a useful enough perspective, and monitoring data series exist to determine if changes have occurred since then.

The assessment process is descriptive and involves three steps. First, we list human activities that are likely to impact the ecosystem. Second, we describe the ecosystem components and their relations in a component tree. This approach allows the identification and consideration of all ${ }^{1}$ components, including those for which no information is available. Third, for each component we identify the "documented" and "possible" pressures caused by the human activities in order to establish the state of the system in the early 1990s. For this, we compiled component assessments from published and grey literature, focusing on those pressures that are significant at the regional scale of the Bay of Biscay.

\section{Material and methods}

Human activities leading to potential pressure on the ecosystem were identified following the guidance provided

${ }^{1}$ All are needed because assessing all human impacts is necessary for an initial assessment of the ecosystem and further monitoring programs. 
by the OSPAR ${ }^{2}$ Commission (2000) and described based on published information. An ecosystem component tree (Fletcher et al. 2005) was drawn and tailored based upon a literature review. Depending on data availability, one or several indicators, in addition to qualitative descriptions, were used to assess the status of each component in the early 1990s. The objective was to classify each component as impacted or not impacted by one of the listed human activities. If impacted, it was determined whether the impact concerned the whole area (widespread impact) or only part of it (local impact). Because evidence of impacts may be weak or lacking in some cases, defining levels of impacts as "acute" or "chronic" (as in ICES 2008) or from "no impact" to "high impact" (as in Johnson 2008) could not be done consistently over all components. Therefore, we used an approach based upon the likelihood of impacts, refined from ICES (2007) as follows:

- No impact likely: pressure of human activity likely to have no or insignificant impact on the ecosystem component;

- Possible impact: pressure of human activity likely to adversely affect the ecosystem component, according to expert knowledge and in the absence of published evidence;

- Documented impact: some published or grey literature evidence available documents the fact that the pressure of human activity affects the component.

Therefore, following ICES (2008) our assessment model allows to build matrices which entries are ecosystem components, human activities and pressures. Impacts of pressures are assessed by spatial extent and likelihood.

The most comprehensive information on ecosystem component status was found for (i) sensitive fish species, i.e. species able to sustain only low levels of total mortality, for which the degree of threat was assessed and provided in the Red List of the International Union for Conservation of Nature (IUCN 2008) and a few other studies; (ii) commercial species for which fishery stock assessments exist (e.g. ICES 1992; Forest 2001); (iii) coastal habitats undergoing eutrophication and contamination, for which time series of nutrients and pollutants are available (RNO 2000; Beliaeff et al. 2005) and (iv) the environment, e.g. physical parameters (Michel et al. 2009).

Most of the component assessments were based upon literature and with little exception the work we cite are scientific literature posterior the 1970s. We did not analyse historical documents but historical knowledge is nevertheless accounted for based upon studies such as Binet (1999), Quéro and Cendredo (1996) and assessments from IUCN (2008).

In the sea, the specific rate of decline and threats for sensitive species are difficult to assess, extinctions are difficult to observe, and there can be a lag of several decades between the last sighting of a marine species and the reported date of extinction (Dulvy et al. 2005). Therefore, the assessment of the degree of threat for a species might improve over time as information accumulates. As the primary historical focus of IUCN was on terrestrial animals, only a small proportion of

\footnotetext{
${ }^{2}$ OSPAR is the mechanism by which fifteen Governments of the western coasts and catchments of Europe, together with the European Community, cooperate to protect the marine environment of the North-East Atlantic.
}

marine fish species has been assessed to date. Therefore, to determine which species were threatened in the early 1990s, we used IUCN assessments carried out up to 2008 for fish and invertebrates and reviewed for which of them the current threats might have already existed in the 1990s. In the case of marine mammals and seabirds, we used IUCN assessments carried out up to 1996. A few additional sources on threatened species in the Bay of Biscay (de Beaufort and Lacaze 1987; Maurin 1994; Quéro and Cendredo 1996) were used.

Commercial species were defined as the main species in the landings from ICES Divisions VIIIa-b for the period 19732006 (http://www.ices.dk/fish/statlant.asp). Assessments, for the early 1990s, carried out at that time or any time later, of every species making more that $0.5 \%$ of the landings in 1973 2006 were searched. A few assessments for species of lesser importance in the landings were also found. We categorised exploited stocks as under, fully or overexploited according to the criteria from the early 1990s, which often implied some interpretation of assessment result and/or management recommendation. Stocks were categorised over-exploited whenever fishing mortality or effort was estimated too high, spawning stock biomass was estimated to be low or declining or when management guidelines requested lower catch/effort or improved fishing pattern.

\section{Results}

\subsection{Description of human activities in the Bay of Biscay}

\subsubsection{Fishing}

Fishing exerts direct pressure on the target species as well as on bycatch commercial and unwanted (discarded) species. It also generates direct pressures on the seabed and benthic communities (Hall 1999; Lindeboom and De Groote 1998), which, in turn affects fish populations and communities. Fishing has a long history on the Eastern shelf of the Bay of Biscay (e.g. Binet 1999). During the decades prior to the early 1990s, the French fleet comprised about 3000 small-scale vessels and almost 1000 larger vessels, mainly 16-25 m-long trawlers fishing at least partly in the Bay (Abbes 1991). The trawlers were based mainly in ports of Southern Brittany and contributed the major part of total fishing effort and production (Abbes 1991; Massoud and Piboubès 1994), while small-scale activities were scattered along the whole coast. In addition, 210 to 240 Spanish trawlers and a number of Spanish long-liners exploited the area (Dardignac 1988). All used a range of fishing gears, from trawls (main gear, especially in the northern area) and dredges to longlines, pots and a wide diversity of nets (Abbes 1991). For example, 52 different gears were listed for the Southern Bay of Biscay alone (Decamps and Léauté 1988). In 1982, the total production of the Bay (ICES Sub-area VIII) was estimated at $174430 \mathrm{t}$ of demersal species and $110400 \mathrm{t}$ of pelagic fish, of which $75800 \mathrm{t}$ were caught by French vessels. The total French production increased to $80500 \mathrm{t}$ in 1984 (Dardignac 1988) and $90000 \mathrm{t}$ in 1997, while the fleet decreased to 2500 vessels (OSPAR Commission 2000). Reported total landings from Spain for the whole ICES Sub-area VIII 
were twice as much as French landings. However, French landings were dominant in the Divisions VIIIa-b on which this study focuses.

Recreational fishing is a favourite pastime in France. A nation-wide study carried out by telephone interviews in 2003 estimated that there were about 4 millions recreational fishers in France, harvesting several thousand tonnes on the Atlantic coast, of which 1 million targeting sea bass (Y. Morizur, Ifremer, pers. comm.).

\subsubsection{Mariculture}

Mariculture induces pressures on the ecosystem by modifying the structural and functional parameters of planktonic and benthic communities and the introduction of nonindigenous species. The latter includes species voluntarily introduced for farming purposes as well as the associated macroand microorganisms (Gruet et al. 1976; Clynick et al. 2008; Molnar et al. 2008). Habitat modifications, including changes in sedimentary processes, may lead to local pressures. Oyster culture (mainly Crassostrea gigas) was and still is a major activity along the French coast, with an overall annual production of $80000 \mathrm{t}$, the main production regions being MarennesOléron and Arcachon (Massoud and Piboubès 1994). About 20000 t mussels (Mytilus edulis) were produced, mainly in the central region (Massoud and Piboubès 1994). There is also a small production of cockles (Cerastoderma edule).

\subsubsection{Maritime transport}

Marine transport induces impacts mainly through: (i) ballast waters carrying invasive species (Molnar et al. 2008) and (ii) diffuse pollution (e.g. oil products) in harbours and at sea and accidental oil spills (National Research Council 2003). It also induces release of pesticides from antifouling paint. However, as merchant ship sail in the open water, this contamination might stay at undetectable levels as suggested by the strong decrease in tributyltin contamination after its ban on vessels smaller than $25 \mathrm{~m}$. Tributyltin however accumulates in harbors sediments, which dumping at sea when dredging port may be a concern (Alzieu 1998). The three main French ports in the Bay of Biscay are Nantes Saint-Nazaire, Bordeaux and La Rochelle, with respectively 25, 10 and 9 million tonnes of cargo handled in 1992 (Massoud and Piboubès 1994). Oil products and food are the main items transported to various regions of France, Europe and the rest of the world. More than $70 \%$ of the total oil consumed in the EU is transported through the English Channel, making oil spills a real risk for the Bay of Biscay (Lavin et al. 2005). No major accidental oil spill impacted the Bay of Biscay before the early 1990s. The "Amoco Cadiz" spill in 1978, which occurred in the Western Channel, spread only to the northern part of the study area. Since the early 1990s, the Bay of Biscay was impacted by two severe oil spills, "Erika" in 1999, and "Prestige" in 2002.

\subsubsection{Sand and gravel extraction}

The recovery from sand and gravel extraction depends on the stability of the habitat concerned, with highly dynamic systems often showing only short-term impacts (ICES 2001). The known reserves of sand and gravel along the French coast amount to $24 \times 10^{9} \mathrm{~m}^{3}$ of siliceous sediments and $0.17 \times 10^{9} \mathrm{~m}^{3}$ of calcareous sediments (OSPAR Commission 2000). Only a small fraction $\left(600 \times 10^{6} \mathrm{~m}^{3}\right)$ of siliceous sediments is currently exploitable at a profit. Extraction in the 1990s amounted to $2.3 \times 10^{6} \mathrm{~m}^{3}$ year $^{-1}$, extracted from claims of a total surface of $29 \mathrm{~km}^{2}$. The Loire estuary is the largest producer (Mauvais and Goarnisson 1999). Smaller amounts of calcareous sand and maerl (Lithothamnion sp., calcified macroalgae, Rhodophyta) were extracted south of Brittany (OSPAR Commission 2000). Extraction has increased in the 1990s and 2000s (Bourcereau et al. 2000; Kalaydjian et al. 2006). Five sites of marine aggregate extraction are presently in activity along the coast of the Bay of Biscay, the largest site still being situated near the Loire estuary.

\subsubsection{Direct waste dumping}

Material dredged in French and Spanish ports is dumped at sea at licensed sites (OSPAR Commission 2000). In the Loire estuary, 6 to $8 \times 10^{6} \mathrm{~m}^{3}$ were dredged annually from 1984 to 1993, which may represent one third to half the total amount dredged in the Bay of Biscay estuaries and ports (Alzieu 1999). Theses quantities increased in the 1990s and decreased in recent years (GIP Loire estuaire 2007). The direct effects of discharges on the benthic community depend on local conditions.

\subsubsection{Terrestrial activities}

Terrestrial sources of impacts on the Bay of Biscay ecosystem come from agriculture-induced pollution, coastal human settlements and tourism. Tourism, coastal agglomerations and the general urbanisation of the coastline generate pressures on the coastal ecosystem and habitats, owing to shore occupation by marinas, dredging, filling, sewage and litter. Small- to medium-scale agriculture is present all along the French coast but cultivated areas declined by 5 to $25 \%$ during the 1980 s (Massoud and Piboubès 1994). However, intensive agriculture in Brittany generates various organic and chemical pollution in the catchment basins and, subsequently, in coastal areas.

As for tourism, the private yachts fleet increased steadily during the 1980s in Nantes and Bordeaux, and a number of yachting ports were created or expanded (Massoud and Piboubès 1994). The whole coast attracts more than 10 million tourists per year, especially in the southern area. During the summer, the population increases three-fold in the regions South of Nantes (OSPAR Commission 2000).

In 1990, two urbanised areas had more than 600000 inhabitants near the French coast, in addition to many smaller towns (OSPAR Commission 2000). The French population of the Atlantic administrative departments increased by $4 \%$ between 1982 and 1990 (after the National Institute of Statistics and Economic Studies - France, INSEE) data (http://www.insee. $\mathrm{fr} /$ ). The resident human population, in a $10 \mathrm{~km}$-wide coastal strip, increased at a similar rate between 1982 and 1990, reaching 1.6 million inhabitants in 1990 (Massoud and Piboubès 1994). Industries of various types are located primarily along 


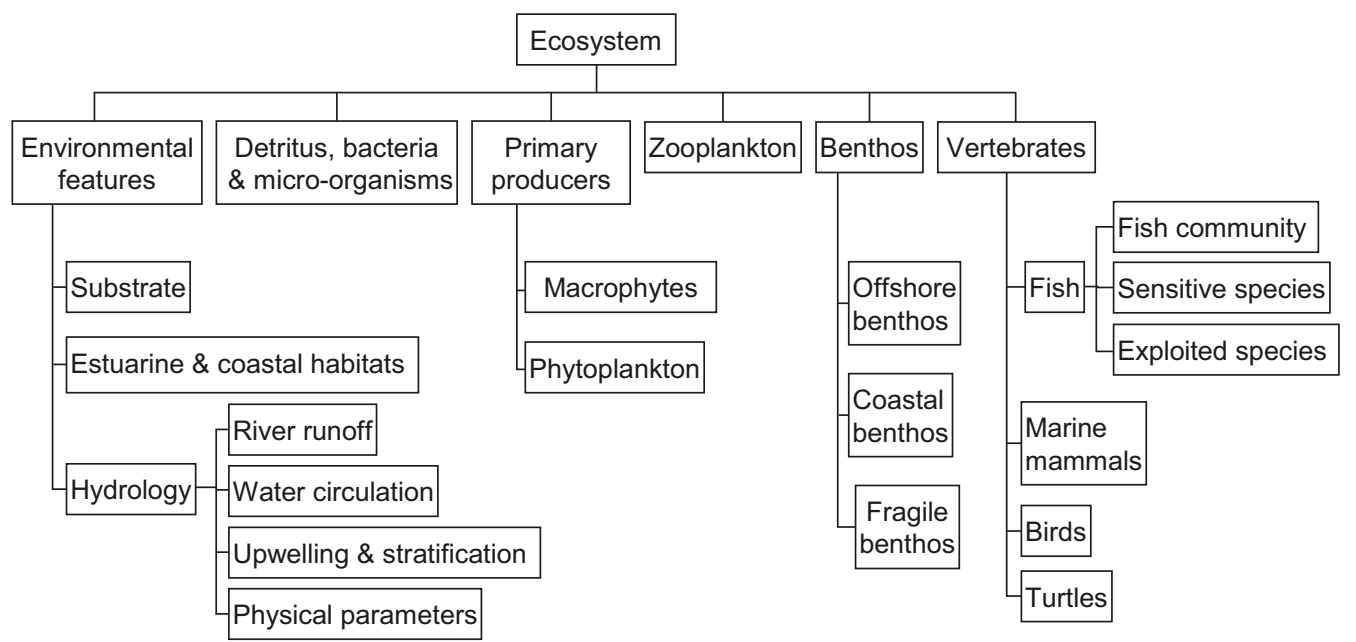

Fig. 2. Component tree of the Bay of Biscay ecosystem.

the Spanish coast, the French coast being less industrialised (OSPAR Commission 2000).

\subsection{Bay of Biscay ecosystem components}

The component tree for the Bay of Biscay ecosystem is comprised of six main branches, one branch for environmental features and five biotic branches (Fig. 2). These main branches are subdivided into 19 components. In the following sub-section, each component is described and its state in the early 1990s is assessed and linked to the human activities that are documented or may affect it. Documented and posible impacts of pressures by human activity and ecosystem components are listed in Table 1 and impacts levels are synthesized as an ecosystem component $\times$ human activity matrice of spatial extent and likelihood of impact (Table 2).

\subsubsection{Environmental features}

Environmental features were described by three components: substrate, estuarine/coastal habitats and hydrology. The latter is subdivided into river runoff, water circulation, upwelling/stratification and physical parameters.

\section{Substrate}

The sediment cover of the continental margin consists mainly of alternating thick and thin sheet-fan deposits. The continental shelf and upper slope sediments originate mostly from the continent. The inner shelf (depth $<100 \mathrm{~m}$ ) substrate is mainly rocky or sandy, whereas the outer shelf is predominantly muddy, with deep canyons on the shelf-break.

One major sedimentary area off Southwest Brittany is known as the Grande Vasière (Fig. 1). It is a large and homogeneous sand blanket that is subject to modern supplies of riverborne fine material. The fine sediment (mud) content does not exceed $30 \%$, and mud occurs mainly in the upper $20-30 \mathrm{~cm}$ (Dubrulle et al. 2007). Comparison of sediment composition and distribution between 1970 (Glemarec 1971) and the early 2000s have shown that the proportion of mud has decreased over the past four decades (Bourillet et al. 2004; Hily et al. 2008; Table 1). Such changes can result from sediment remobilisation due to storms but can also be due to towed fishing gear. Although the respective contribution of each cause to the observed changes is unknown, it seems likely that trawling in this area has contributed to a change in the sediment composition because resuspended small particles (mud) remain longer in the water than sand and are exported by currents (de Madron et al. 2005; Ferre et al. 2008; Hily et al. 2008).

The main rivers bring $2.5 \times 10^{6} \mathrm{ty}^{-1}$ of fine sediment (mud) to the Bay of Biscay; Gironde contributes to more than half this amount (Jouanneau et al. 1999). Considerable quantities of sand and gravels were extracted from rivers until the 1980s, extraction from the Loire was estimated to correspond to 400 years of bedload transport removed from 1945 to 1980 (Belleudy 2000). This might be expected to have reduced the amount of sand brought by the river, while its effect on the mud fraction is unknown. Extractions from the river bed ceased in the early 1990s. Other terrestrial activities might have had an impact too, the overall balance is not known and no time series of sediment input from rivers was found. Impacts of mariculture, sand/gravel extraction and waste dumping are treated below, as they occur only in coastal areas.

Then, at the reference time, the substrate was regionally impacted by fishing. Terrestrial activities may have impacted the sediment input.

\section{Estuarine and coastal habitats}

According to hydrodynamical processes, the Bay of Biscay estuarine and coastal areas have been grouped into open estuarine areas and semi-enclosed bays. The former are under direct influence of freshwater inflows and are characterized by salinity gradients. The Bay of Vilaine and the Gironde and Loire estuaries fall within this category (Fig. 1). They receive an average river flow of $91 \mathrm{~m}^{3} \mathrm{~s}^{-1}, 935 \mathrm{~m}^{3} \mathrm{~s}^{-1}, 780 \mathrm{~m}^{3} \mathrm{~s}^{-1}$ respectively, Gilliers et al. 2006). The Bay of Bourgneuf, the Pertuis Breton and the Pertuis d'Antioche show environmental 


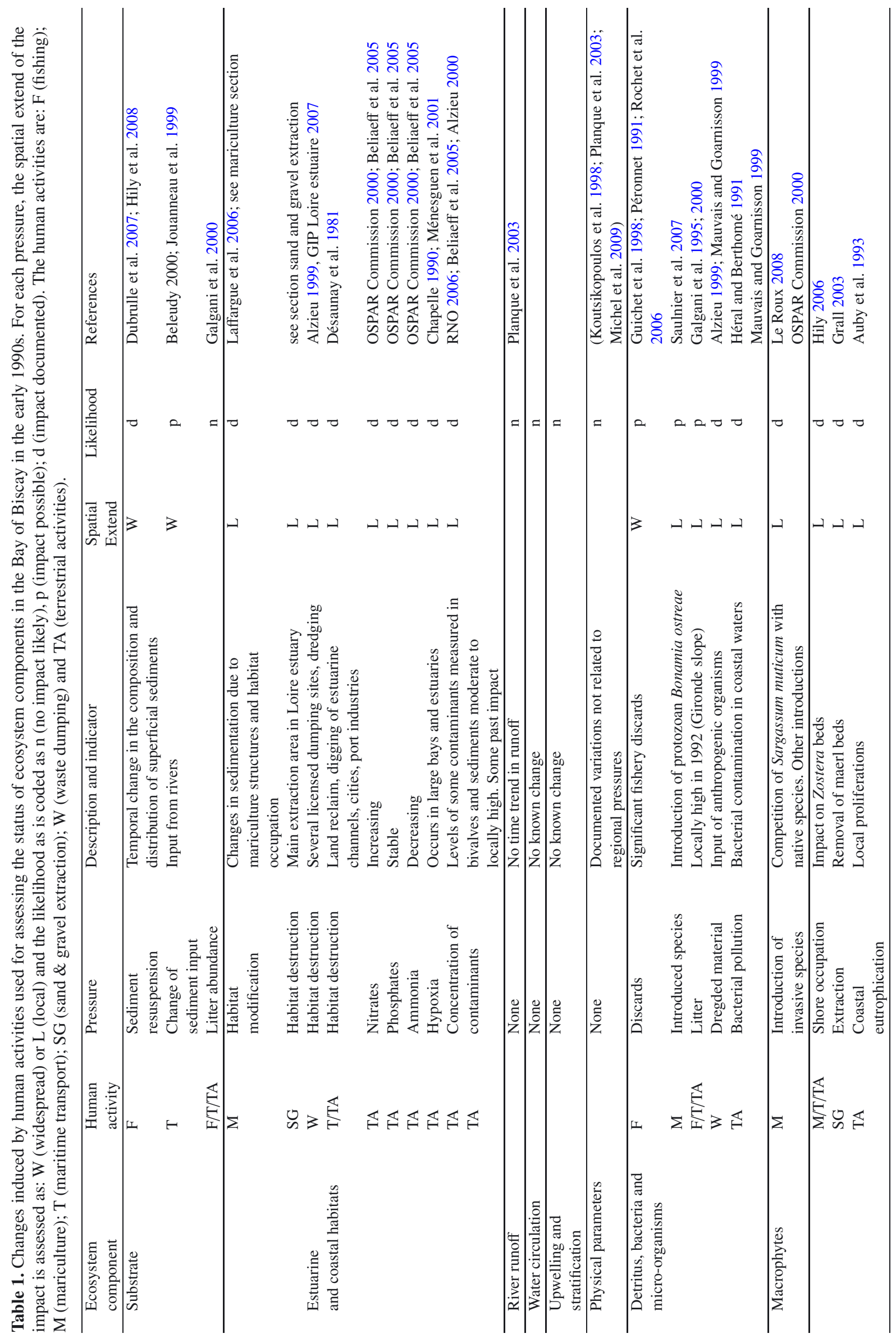




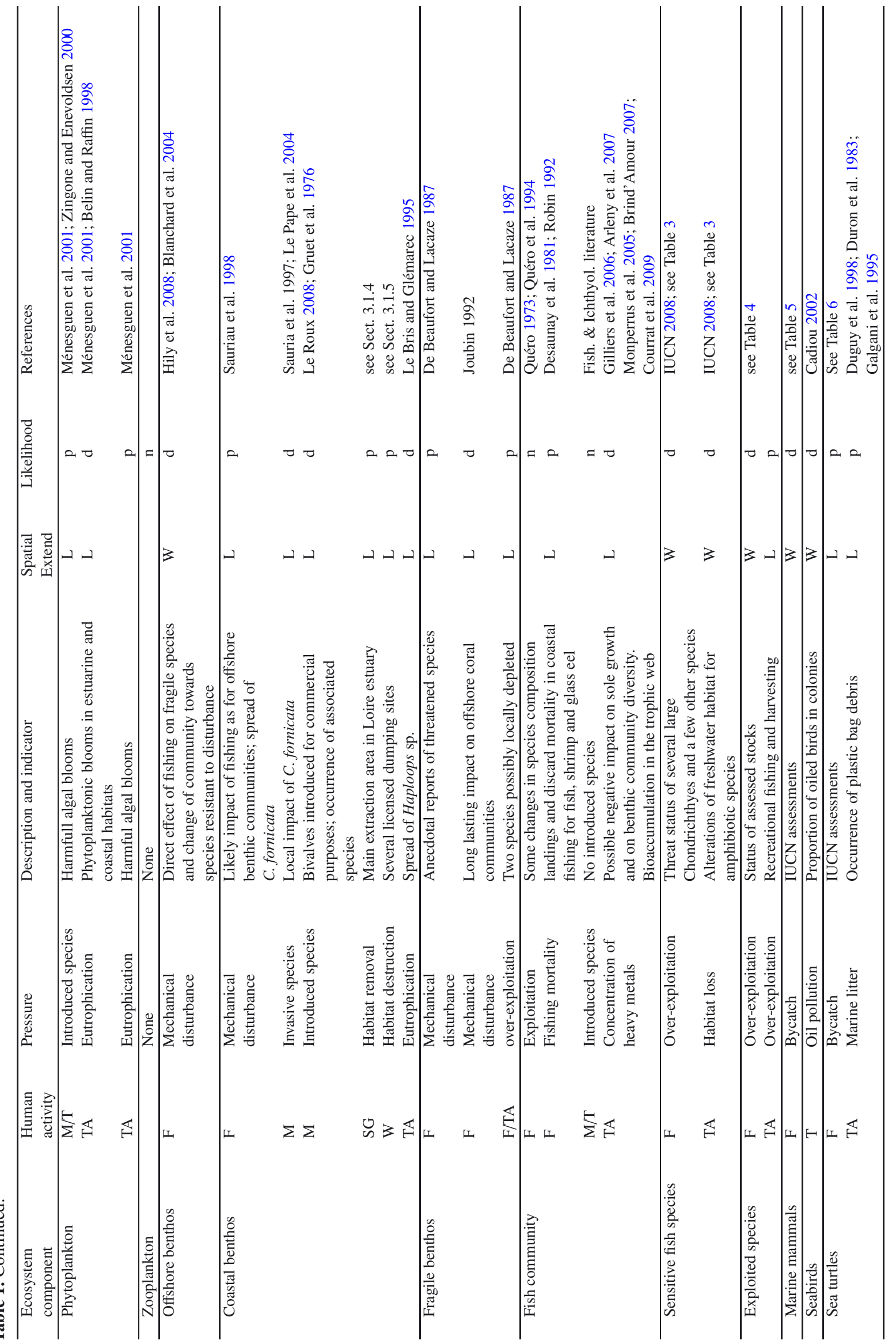


Table 2. Human activities with documented impacts on ecosystem components in the Bay of Biscay in the early 1990s. Spatial extend of the impact is coded as W (Widespread); L (Local). Likelihood is coded as n (no impact likely); p (impact possible); d (impact documented).

\begin{tabular}{|c|c|c|c|c|c|c|}
\hline Ecosystem component & Fishing & Mariculture & Transport & $\begin{array}{c}\text { Sand \& gravel } \\
\text { extraction }\end{array}$ & $\begin{array}{c}\text { Waste } \\
\text { dumping }\end{array}$ & $\begin{array}{l}\text { Terrestrial } \\
\text { activities }\end{array}$ \\
\hline \multicolumn{7}{|l|}{ Environmental features } \\
\hline Substrate & $\mathrm{W} / \mathrm{d}$ & $\mathrm{n}$ & $\mathrm{n}$ & $\mathrm{n}$ & $\mathrm{n}$ & $\mathrm{W} / \mathrm{p}$ \\
\hline Estuarine and coastal habitats & $\mathrm{n}$ & $\mathrm{L} / \mathrm{d}$ & $\mathrm{L} / \mathrm{d}$ & $\mathrm{L} / \mathrm{d}$ & $\mathrm{L} / \mathrm{p}$ & $\mathrm{L} / \mathrm{d}-\mathrm{W} / \mathrm{p}(1)$ \\
\hline Hydrology (4 sub-components) & $\mathrm{n}$ & $\mathrm{n}$ & $\mathrm{n}$ & $\mathrm{n}$ & $\mathrm{n}$ & $\mathrm{n}$ \\
\hline Detritus and bacteria & $\mathrm{W} / \mathrm{p}$ & $\mathrm{L} / \mathrm{p}$ & $\mathrm{L} / \mathrm{p}$ & $\mathrm{n}$ & $\mathrm{L} / \mathrm{d}$ & $\mathrm{L} / \mathrm{d}$ \\
\hline \multicolumn{7}{|l|}{ Primary producers } \\
\hline Macrophytes & $\mathrm{n}$ & $\mathrm{L} / \mathrm{d}$ & $\mathrm{L} / \mathrm{d}$ & $\mathrm{L} / \mathrm{d}$ & $\mathrm{n}$ & $\mathrm{L} / \mathrm{d}$ \\
\hline Phytoplankton & $\mathrm{n}$ & $\mathrm{L} / \mathrm{p}$ & $\mathrm{L} / \mathrm{p}$ & $\mathrm{n}$ & $\mathrm{n}$ & $\mathrm{L} / \mathrm{d}$ \\
\hline Zooplankton & $\mathrm{n}$ & $\mathrm{n}$ & $\mathrm{n}$ & $\mathrm{n}$ & $\mathrm{n}$ & $\mathrm{n}$ \\
\hline \multicolumn{7}{|l|}{ Benthos } \\
\hline Offshore benthos & $\mathrm{W} / \mathrm{d}$ & $\mathrm{n}$ & $\mathrm{n}$ & $\mathrm{n}$ & $\mathrm{n}$ & $\mathrm{n}$ \\
\hline Coastal benthos & $\mathrm{L} / \mathrm{p}$ & $\mathrm{L} / \mathrm{d}$ & $\mathrm{n}$ & $\mathrm{L} / \mathrm{p}$ & $\mathrm{L} / \mathrm{p}$ & $\mathrm{L} / \mathrm{d}$ \\
\hline Sensitive benthos & $\mathrm{L} / \mathrm{d}$ & $\mathrm{n}$ & $\mathrm{n}$ & $\mathrm{n}$ & $\mathrm{n}$ & $\mathrm{L} / \mathrm{d}$ \\
\hline \multicolumn{7}{|l|}{ Vertebrates } \\
\hline \multicolumn{7}{|l|}{ Fish } \\
\hline Fish community & $\mathrm{L} / \mathrm{p}$ & $\mathrm{n}$ & $\mathrm{n}$ & $\mathrm{n}$ & $\mathrm{n}$ & $\mathrm{L} / \mathrm{d}$ \\
\hline Sensitive fish species & $\overline{\mathrm{W} / \mathrm{d}}$ & $\mathrm{n}$ & $\mathrm{n}$ & $\mathrm{n}$ & $\mathrm{n}$ & $\overline{\mathrm{W} / \mathrm{d}}$ \\
\hline Exploited species & $\mathrm{W} / \mathrm{d}$ & $\mathrm{n}$ & $\mathrm{n}$ & $\mathrm{n}$ & $\mathrm{n}$ & $\mathrm{L} / \mathrm{p}$ \\
\hline Marine mammals & $\mathrm{W} / \mathrm{d}$ & $\mathrm{n}$ & $\mathrm{n}$ & $\mathrm{n}$ & $\mathrm{n}$ & $\mathrm{n}$ \\
\hline Seabirds & $\mathrm{n}$ & $\mathrm{n}$ & $\mathrm{W} / \mathrm{d}$ & $\mathrm{n}$ & $\mathrm{n}$ & $\mathrm{n}$ \\
\hline Sea Turtles & $\mathrm{L} / \mathrm{p}$ & $\mathrm{n}$ & $\mathrm{n}$ & $\mathrm{n}$ & $\mathrm{n}$ & $\mathrm{L} / \mathrm{p}$ \\
\hline
\end{tabular}

(1): Several local impact are found (see Table 1 and text), so that all the ecosystem component is possibly impacted.

features associated with the second type. They are principally characterized by uniform salinity and temperature conditions within the water column.

The six above-mentioned coastal areas in the Bay of Biscay have been identified as essential habitats for nearly 55 bentho-demersal species of fish, molluscs, arthropods and echinoderms (Guérault et al. 1996). They are spawning grounds, e.g. for European smelt (Osmerus eperlanus), pathways for amphihaline migratory species such as eel (Anguilla anguilla), salmon (Salmo salar) and shads (Alosa sp.) and most significantly, nursery grounds for many commercial species like common sole (Solea solea), wedge sole ( $\mathrm{Di}$ cologlossa cuneata), plaice (Pleuronectes platessa), flounder (Platichthys flesus), sea bass (Dicentrarchus labrax) and whiting (Merlangius merlangus). High survival, maximum growth and high abundance of early life stages are the principal characteristics of nurseries (Gibson 1994).

Monitoring of coastal habitats since the late 1970s shows contamination by several metal and organic contaminants (Beliaeff et al. 2005, Table 1). Before the 1990s, some areas were polluted by tributyltin (from antifouling paints), the use of which was regulated from 1982 onwards (Alzieu 2000). Bioaccumulation of metal and organometal contaminants in some species and trophic groups has been reported (e.g. Arleny et al. 2007; Monperrus et al. 2005). Recently, metal and organic contaminants have been shown to impact negatively common sole growth as well as density and species richness in nurseries (Gilliers et al. 2006; Brind'Amour 2007; Courrat et al. 2009).

Although their ecological consequences are poorly known, sand and gravel extraction, digging in ports and estuaries as well as associated waste dumping induced local habitat destruction (Désaunay et al. 1981; Mauvais and Goarnisson 1999). Coastal sedimentary processes and habitats are also locally impacted by mariculture (Laffargue et al. 2006). Locally, these impacts might be lesser than those from sand and extraction and waste dumping but they may be nonetheless significant owing to the widespread distribution of mariculture activities. Nevertheless, their ecological impact, e.g. on the functioning of coastal habitats as flatfish nurseries is poorly known.

Hypoxia induced major mortality of large organisms only once in 1982 in the Bay of Vilaine, (Chapelle 1990; Le Bris and Glémarec 1995; Ménesguen et al. 2001, Table 1). Since the late 1990s, hypoxia has also been observed in the Gironde and Loire estuaries (Abril et al. 1999, 2003; Ménesguen et al. 2001), without visible mortality of megafauna. In the early 1990s, nitrate concentrations were increasing, phosphates were stable and ammonia was decreasing (Table 1).

In summary, in the early 1990s anoxic events and chemical pollution led to local impacts on estuarine and coastal habitats, and the increase of nutrient levels due to anthropogenic inputs generated local eutrophication (Table 2). In addition, it is possible that recreational intertidal harvesting and tourism exerted direct local pressures while sand/gravel extraction, marine transport, waste dumping, terrestrial activities and shellfish farming certainly did (Table 2).

\section{Hydrology}

Tidal currents, river plumes, seasonal stratification and local upwellings are some of the major hydrological features in 
the Bay of Biscay (Lavin et al. 2005). Long-term river runoff time series show strong year-to-year variations without clear trends (Planque et al. 2003, Table 1) although total runoff was below average in 1989-1991 and induced smaller freshwater plumes and higher surface salinities. Temperature and salinity in the Bay of Biscay were not closely monitored before the 1960s. However, time series going back to 1862 suggest that temperature in the early 1990s was within the long-term fluctuation range and not higher than in the 1950s. The Bay of Biscay displays decadal variations in temperature (Michel et al. 2009), and the early 1970s were a period of cooler temperatures so that the early 1990 s were preceded by 20 years of warming of about $0.75{ }^{\circ} \mathrm{C}$ at $50 \mathrm{~m}$ depth and about $0.5^{\circ} \mathrm{C}$ at $100 \mathrm{~m}$. None of the regional human activities listed above had any direct impact on the hydrology components (Tables 1 and 2).

\subsubsection{Detritus, bacteria and other micro-organisms}

The role of bacteria in nutrient processes and organicmatter flows in the Bay of Biscay is poorly known. Fisheries discards might be expected to impact the level of organic detritus, litter and pollution from terrestrial activities and marine transport might also impact this component. Dumping of material dredged in ports implies at least a local input of anthopogenic micro-organisms (Alzieu 1999).

There is no general assessment of the effects of human activities on the bacteria, viruses, other micro-organisms (e.g. parasites) and detritus material in the Bay of Biscay, but a few examples of adverse impacts are known, such as that of the protozoan Bonamia ostreae on oyster farming in the 1970s and 1980s. B. ostreae was probably imported with Ostrea edulis from California (Saulnier et al. 2007). It induced mass mortality of native farmed $O$. edulis and hence a severe economic loss (Meuriot and Grizel 1984). There is a bacterial contamination in coastal waters from sewage runoffs (Héral and Berthomé 1991). In the 1980s some areas were not suitable for bivalve farming or fishing due to risks of bacterial or viral contamination to consumers (Table 1). During the early 1990s, the situation improved to some extent for shellfish production and bathing waters (Mauvais and Goarnisson 1999).

In summary, it can be assumed that, in the early 1990s, this ecosystem component was impacted to an unknown extent on the regional scale by fishery discards and presumably on a local scale as a result of the introduction of non-indigenous species by mariculture, litter from various sources and anthropogenic bacterial contamination (Table 2).

\subsubsection{Primary producers}

Primary production in the Bay of Biscay originates mainly from the pelagic domain. However, macrophytes can be locally abundant along the coast. Significant kelp fields occur and are subject to longstanding exploitation off western Brittany (Arzel 1998). The North of the study area can be considered as the southern limit of such exploitation, for which Laminaria digitata is the commercially most interesting species.

\section{Macrophytes}

Two species of eelgrass (Zostera spp.) occur in the Bay of Biscay. Maerl beds formed by unattached red calcareous algae occur locally and provide habitats of high benthic macroalgae, macrofauna and megafauna diversity of more than 50,180 and 60 species respectively (Grall et al. 2006). Gruet (1989) listed about 50 species of large macrophytes in the Bay of Biscay.

In the early 1990s, macrophyte communities were impacted by introduced species. At least thirteen non-indigenous species have been observed, most of them arrived with mariculture imports (Table 1). The Japanese seaweed (Sargassum muticum), introduced together with the farmed Japanese oyster Crassostrea gigas, was first observed in the 1970s. Its abundance increased in the 1980s, it became one of the main macrophyte species, representing a major human induced change in this community (Le Roux 2008). Direct impacts on eelgrass beds, changes in competition with other primary producers due to ports (marine transport and tourism) and mariculture and, above all, macroalgal proliferation due to eutrophication were also reported (Auby et al. 1993; Hily 2006; Ménesguen 2003; Ménesguen et al. 2001). Maerl extraction induces the local removal of beds and associated biodiversity (Grall 2003). There is thus clear evidence that, at the reference time, macrophytes were locally impacted by terrestrial activities (eutrophication), sand and gravel extraction, marine transport and mariculture (shore occupation) (Tables 1 and 2).

\section{Phytoplankton}

At least 1000 phytoplankton species have been identified in OSPAR region IV, which is centred on, but much larger than, the Bay of Biscay (OSPAR Commission 2000). The average total primary production over the whole Bay of Biscay shelf, estimated from a primary production model coupled to a hydrodynamic model and using satellite data (Gohin et al. 2005; Huret et al. 2007; Huret et al. 2009), was estimated at $88.6 \mathrm{~g} \mathrm{C} \mathrm{m}^{-2} \mathrm{y}^{-1}$ from 1980 to 1990 without trend over this period and it was at similar level in the 1990s (Huret, unpublished results). Light level and river plume strength seem to be the major factors regulating the winter-to-spring phytoplankton productivity in the Bay of Biscay (Labry et al. 2001; Gohin et al. 2003). By March-early April, the spring bloom covers the entire shelf area. From May onwards, the chlorophyll level drops sharply offshore due to nutrient shortage, while low chlorophyll values are observed in summer. Phosphorous is the first limiting factor during late winter and spring blooms (Labry et al. 2002). Hydrological slope processes favour blooms - sometimes due to coccolithophorids that are regularly observed from satellite images over the shelf break from April to October (Lampert et al. 2002). Owing to eutrophication, local phytoplanktonic blooms occur in estuaries and river plumes (Ménesguen et al. 2001). It is not clear whether harmful algal blooms (HAB) are increased by eutrophication; species responsible for HAB may be introduced by marine transport and mariculture (Ménesguen et al. 2001; Zingone and Enevoldsen 2000) but there are no evidence of these in the Bay of Biscay. Thus, terrestrial activities had a local (coastal) impact on phytoplankton in the early 1990s but 
the possible impacts from mariculture and marine transport (HAB) are not confirmed (Table 2). The overall level of primary production at the regional scale of the Bay of Biscay might not have been impacted by human activities at the reference time.

\subsubsection{Zooplankton}

Three hundred species of zooplankton have been identified in the Bay of Biscay, among which $10 \%$ are copepods (Poulet et al. 1996). Copepods make up 70 to $90 \%$ of zooplankton and only about ten species make a significant contribution to biomass and secondary plankton production (D'Elbée 2001). Whether or not temporal changes occurred in the zooplankton community, before the 1990 s, either due to natural or human factors, is unknown.

\subsubsection{Benthos}

Three components were considered for the benthos: offshore, coastal and fragile benthos. Fragile benthic species are those that would be the first to disappear under mechanical disturbance of the seabed, especially by towed bottom fishing gears (OSPAR Commission 2006). We found no complete checklist of the benthic species richness in the Bay of Biscay. The meiofauna might be the lesser known of the benthos components. Some microbenthic groups count several hundreds of species.

\section{Offshore benthos}

According to past and recent studies in the offshore Bay of Biscay, crustaceans, followed by molluscs and echinoderms, dominate the macrofaunal species richness, while, in the megafauna, molluscs are more numerous. The megafaunal biomass is smaller than the macrofaunal biomass. The benthic community of the external shelf margin is dominated by carnivorous polychaetes on sandy-mud shelf bottoms, and by deposit feeders on fine sand bottoms (Le Danois 1948; Glémarec 1969; Le Loc'h et al. 2008).

Macrobenthic communities on the Grande Vasière (Fig. 1) were sampled in 1966, and the same sampling gear and scheme were deployed again in 2001-2002. A comparison of the species composition in the two periods revealed a strong change in community structure, which was primarily ascribed to the direct effects of fishing, with a possible additional effect of a change in sediment composition probably also caused by trawling (see section on substrate above). Not surprisingly, the abundance of small mobile deposit feeders and carnivores increased and large epibenthic sessile species decreased (Hily et al. 2008). In the 2000s, comparison of locations exposed to different trawling frequencies gave similar results (Blanchard et al. 2004). As trawling has been widespread for about 100 years in the Bay of Biscay, it is clear that the benthic community on the Grande Vasière was impacted in the early 1990s due to both a direct impact of trawling and a possible indirect impact mediated by a change in habitat suitability (Table 2).

\section{Coastal benthos}

Nearshore endo- and epi-benthic communities characterizing the soft fine sandy and muddy habitats in the nurseries of the Bay of Biscay are mainly composed of Polychaeta (tubeworm Pectinaria koreni), Ophiuroidea (Ophiothrix fragilis, Ophiura sp.), and Mollusca (Cerastoderma edule, Abra alba). These species represent over $80 \%$ of the total endoand epi-benthos density (unpublished data). Various bivalves are exploited in coastal areas, including scallops (Pecten maximus) and smaller species such as cockles (Cerastoderma edule) and truncate donax (Donax denticulatus). The spreading of the small amphipoda Haploops tubicola has been noted over a 20-year period in the Bay of Vilaine and more recently in the Bay of Concarneau and Loire estuary (Désaunay et al. 2006; Le Bris and Glémarec 1995). Increasing nutrient discharges and growing eutrophication may be the cause (Le Bris and Glémarec 1995). Several benthic species have been introduced in the Bay of Biscay, some of which have become abundant. Two large-sized introduced mollusc species occur in coastal waters. The commercial Japanese littleneck (Venerupis phillippinarum) was introduced for aquaculture purposes. The species now forms locally exploited stocks. The slipper limpet (Crepidula fornicata), an introduced invasive species of no commercial interest, is also locally abundant. Its spreading may be increased by trawling activities (Sauriau et al. 1998). It may be a competitor of native filter feeders and it has a negative impact on substrate availability for juvenile sole in their nurseries (Le Pape et al. 2004). In the Pertuis Charentais, more than 850 benthic macrofauna species have been recorded since the XVIII century for soft bottoms alone and this was considered to be an underestimate. Sixty species were recorded for the first time in 1995 . This can be partly explained by the high sampling effort in this year, but may also be related to the effect of the slipper limpet, which habitat modification may have favour some polychaetes species (De Montaudouin and Sauriau 2000). Hence, in the early 1990s, coastal benthos had been altered by terrestrial activities (eutrophication), mariculture (introduction of non-native species) and possibly by fishing (Table 2). These impacts were probably only local; however, the spread of the slipper limpet may compete both for space (in the case of sole) and food (in the case of bivalves). Lastly, sand and gravel extraction and waste dumping might have had local impacts (Alzieu 1999).

\section{Fragile benthos}

De Beaufort and Lacaze (1987) recorded that three threatened species occurred near shore in the Bay of Biscay: the introduced Bryozoa Watersipora aterrima, the bivalve Pteria hirundo and the gastropod Aporrhais pespelecani. Because it is not indigenous, the threat status of the Bryozoa is not considered here. The bivalve and the gastropod were threatened by their over-exploitation by professional and recreational divers. However, as both species also occur offshore (Martin 2009), these threats might be only local. There are no marine invertebrates from the Bay of Biscay on the IUCN threatened species list. Only the edible sea urchin Echinus esculentus was assessed as being in the Lower Risk category, near threatened 
in 1996, after having been classified in the Data Deficient category earlier in the 1990s and 1980s. There is also no invertebrate from the Bay of Biscay on the threatened species list from Maurin (1994).

Offshore benthic communities comprise locally cold-water coral. Reefs of Lophelia pertusa occur on the outer shelf and upper slope and are known to be highly sensitive to towed fishing gears (Rogers 1999). A few obviously fragile species like the bivalves Atrina pectinata and Pteria hirundo occur locally on the shelf, at low density. Cold-water corals occurring on the outer shelf and upper slope and other sessile fauna have been subject to impacts by towed fishing gears since the late $20^{\text {th }}$ century (Joubin 1922; Table 2). Thus, the current distribution of cold-water corals might correspond to the deeper end of their pristine distribution. Consequently, the distribution of fragile benthos was clearly impacted by fishing in the early 1990s and a few species may have been impacted by recreational and commercial fishing at the coast (Table 2).

\subsubsection{Vertebrates}

Four main vertebrate components were considered: fish, marine mammals, seabirds and turtles. Within fish we considered the fish community as a whole as well as sensitive fish species and exploited species (including commercial invertebrates) as separate components.

\section{Fish community}

The main pelagic fish species are pilchard (Sardina pilchardus), anchovy (Engraulis encrasicolus), mackerel (Scomber scombrus), horse mackerel (Trachurus trachurus) and blue whiting (Micromesistius poutassou). Chub mackerel (Scomber colias) and Mediterranean horse mackerel (Trachurus mediterraneus) occur at lower densities. Albacore (Thunnus alalunga), and to a lesser extent, Northern bluefin tuna (Thunnus thynnus) occur seasonally along the shelf break. The most important large demersal fish species are hake (Merluccius merluccius), megrims (Lepidorhombus spp.), monkfishes (Lophius spp.) and common sole ( $S$. solea). The main elasmobranch species on the shelf are rays: thornback ray (Raja clavata), spotted ray (Raja montagui) and cuckoo ray (Leucoraja naevus), and the lesser-spotted catshark (Scyliorhinus canicula), distributed from the coast to the outer shelf, the Spanish dogfish (Galeus melastomus) on the outer shelf and upper slope, and the spurdog (Squalus acanthias). Widely migratory sharks such as blue shark (Prionace glauca), shortfin mako (Isurus oxyrhynchus), porbeagle, tope (Galeorhinus galeus) also occur in the Bay of Biscay (Quéro et al. 1989; Sánchez et al. 2005).

The total known fish species richness in the Bay of Biscay (ICES Sub-area VIII) amounts to 576 species (Quéro et al. 2003). No biogeographical data to assess species richness at a smaller spatial scale, i.e. the eastern shelf only, was found. This quite high fish species richness may be explained by the co-occurrence of sub-tropical, temperate and boreal species. However, only five species make up more than $50 \%$ of the total biomass and abundance of demersal fish as estimated by bottom trawl surveys (Blanchard 2001). On the outer shelf and upper slope, the demersal fish community is dominated in number by juvenile blue whiting.

The reported changes in the fish community include increased abundance and spreading towards higher latitudes of a few rather rare sub-tropical species, related to warming (Quéro et al. 1998). Increased abundance and spreading was also observed for the grey triggerfish (Balistes capriscus), which was rare in the early 1970 s and occasionally gave rise to high catches in the early 1990s (Quéro 1973; Quéro et al. 1994). It is nowadays regularly caught. However, these changes can be considered as minor, hence, the Bay of Biscay fish community showed no widespread impact by human activities at the reference time, whereas such impacts are most likely local in coastal areas, as described above (Table 2). There are no known introduced fish species in the Bay of Biscay. There is evidence of strong changes at species level (see below), which imply changes in the species composition at community level. It is difficult to determine the extent to which these changes may have altered the community's functioning. Therefore, these changes are considered here only at species level. Further changes in species composition have been reported since the reference time (Blanchard and Vandermeirsch 2003; Poulard and Blanchard 2005).

Fishery discards have been high for a long time in the Bay of Biscay, in particular in the Nephrops trawl fishery (Guichet et al. 1998; Péronnet 1991; Rochet et al. 2006; Table 1). Discard levels might even have decreased since the 1980s, following implementation of management measures, including increases in mesh sizes. In addition to direct impacts on fish populations, there are indirect impacts on several ecosystem components due to changes in the food web by providing readily available food to scavenging invertebrates, fish and seabirds (Bergmann et al. 2002; Olaso et al. 1998).

Coastal fishing for the brown shrimp (Crangon crangon), the glass eel (A. anguilla) and fish is known to have generated serious mortality on juvenile fish in coastal nurseries (Désaunay et al. 1981; Robin 1992). This effect was probably on the decrease in the 1990s due to the reduced number of shrimp trawlers (Poulard and Léauté 2002).

Therefore, this latter impact is considered here as a possible local impact on coastal fish communities, in the early 1990s. Terrestrial activities are also considered to affect fish communities due to the negative effect of contamination of coastal nurseries (see section on estuarine and coastal habitats). Changes in species composition, due to depletion of sensitive species and overexploitation are accounted for below.

\section{Sensitive fish species}

By 2008, IUCN had assessed a total of 70 species of Agnatha, Chondrichthyes and Actynopterygians occurring in the Bay of Biscay. Of the 69 species assessed, 21 live in deep waters and were assessed in the 2000s. Some of those may be currently threatened due to the development of deep-water fisheries since the late 1980s and early 1990s but were not threatened at the reference time and are not included here. A further set of 14 Chondrychthyes were assigned by IUCN 
Table 3. Fish populations in the Bay of Biscay assessed by IUCN (2008) or considered threatened in other studies.

\begin{tabular}{|c|c|c|c|c|}
\hline Species & $\begin{array}{l}\text { Current (previous, if } \\
\text { different) IUCN } \\
\text { RedList assessment }\end{array}$ & Maurin (1994) & $\begin{array}{c}\text { de Beaufort and Lacaze } \\
\text { (1987) }\end{array}$ & Quéro and Cendredo (1996) \\
\hline Petromyzon marinus Linnaeus, 1758 & $\mathrm{LR} / \mathrm{lc}$ & VU & Several threats & \\
\hline Lampetra fluviatilis (Linnaeus, 1758) & $\mathrm{LR} / \mathrm{nt}$ & VU & & \\
\hline Alosa alosa (Linnaeus, 1758) & $\mathrm{DD}$ & $\mathrm{VU}$ & Several threats, locally extinct & \\
\hline Alosa fallax (Lacepède, 1803) & $\mathrm{DD}$ & VU & Several threats & \\
\hline Salmo trutta Linnaeus, 1758 & $\mathrm{LR} / \mathrm{lc}$ & VU & & \\
\hline Salmo salar Linnaeus, 1758 & $\mathrm{LR} / \mathrm{lc}$ & VU & Several threats, locally extinct & \\
\hline Anguilla anguilla (Linnaeus, 1758) & & $\mathrm{VU}$ & Severe recent decline & \\
\hline Acipenser sturio Linnaeus, 1758 & $\mathrm{CR}$ & EN & Depleted & \\
\hline Hippocampus guttulatus Cuvier, 1829 & $\begin{array}{c}\mathrm{DD}(\mathrm{VU} \text { in } 1996 \text { as } \\
\text { H. ramulosus and } \\
\text { H. longirostris) }\end{array}$ & $\begin{array}{c}\mathrm{VU} \text { (as } \\
\text { H. ramulosus) }\end{array}$ & $\begin{array}{l}\text { As } H \text {. ramulosus, decreased } \\
\text { abundance (1) }\end{array}$ & \\
\hline Hippocampus hippocampus (Linnaeus, 1758) & $\mathrm{DD}$ (VU in 1996) & & & \\
\hline Pagrus pagrus (Linnaeus, 1758) & EN & & & \\
\hline Thunnus alalunga (Bonnaterre, 1788 ) & $\mathrm{VU}$ & & & \\
\hline Thunnus thynnus (Linnaeus, 1758) & EN & & & \\
\hline Xiphias gladius Linnaeus, 1758 & EN & & & \\
\hline Trigla lyra Linnaeus, 1758 & & & & EN \\
\hline Carcharhinus plumbeus (Nardo, 1827) & LR/nt (VU in 1996) & & & \\
\hline Carcharodon carcharias (Linnaeus, 1758) & VU (DD in 1990 and 94) & & & \\
\hline Cetorhinus maximus (Gunnerus, 1765) & EN & & & \\
\hline Dipturus batis (Linnaeus, 1758) & $\mathrm{CR}$ & $\mathrm{VU}$ & Disappearance from landings & $\mathrm{EN}$ \\
\hline Dipturus oxyrinchus (Linnaeus, 1758) & NT & VU & Disappearance from landings & EN \\
\hline Echinorhinus brucus (Bonnaterre, 1788) & $\mathrm{DD}$ & $\mathrm{VU}$ & Disappearance from landings & EN \\
\hline Galeorhinus galeus (Linnaeus, 1758) & VU & & & $\mathrm{VU}$ \\
\hline Hexanchus griseus (Bonnaterre, 1788) & LR/nt (VU in 1996) & & & \\
\hline Lamna nasus (Bonnaterre, 1788 ) & $\mathrm{CR}$ & & & \\
\hline Raja clavata Linnaeus, 1758 & $\mathrm{LR} / \mathrm{nt}$ & $\mathrm{VU}$ & Became less common in landings & \\
\hline Rostroraja alba (Lacepède, 1803) & EN & EN & Disappearance from landings & EN \\
\hline Squalus acanthias Linnaeus, 1758 & $\mathrm{CR}$ & & & Severely rarefied \\
\hline Squatina squatina (Linnaeus, 1758) & $\mathrm{CR}$ & $\mathrm{VU}$ & Disappearance from landings & EN \\
\hline Scyliorhinus stellaris (Linnaeus, 1758) & & $\mathrm{VU}$ & Decreased abundance & \\
\hline Raja brachyura Lafont, 1873 & & $\mathrm{VU}$ & Became less common in landings & $\mathrm{VU}$ \\
\hline Dasyatis pastinaica (Linnaeus, 1758 ) & & & & $\mathrm{VU}$ \\
\hline Myliobatis aquila (Linnaeus, 1758) & & & & $\mathrm{VU}$ \\
\hline Mustelus asterias Cloquet, 1821 & & & & $\mathrm{VU}$ \\
\hline Mustelus mustelus (Linnaeus, 1758) & & & & $\mathrm{VU}$ \\
\hline
\end{tabular}

IUCN criteria: CR (critically endangered); EN (endangered); VU (vulnerable); LR (lower risk); nt (near threatened); lc (least concern); DD (data deficient). Classifications lc and nt are from the IUCN 1994 Categories \& Criteria (version 2.3), for species that were not assessed under the current classification scheme (see http://www.iucnredlist.org/static/categories_criteria)

to the Near Threatened, Lower Risk and Data defficient categories and were not reported as threatened in other studies. Lastly, threatened species which were much more abundant in other areas than in the Bay of Biscay were not considered here because their depletion is not due to threats occurring in the Bay of Biscay nor can any mitigation actions taken in the Bay of Biscay contribute significantly to their possible restoration. This is the case for three boreal species, cod (Gadus morhua), haddock (Melanogrammus aeglefinus) and halibut (Hippoglossus hippoglossus), and two subtropical and Mediterranean species, dusky grouper (Epinephelus marginatus) and brown meagre (Sciaena umbra). Similarly, two Chondrichthyes, devil fish (Mobula mobular) and common guitarfish (Rhinobatos rhinobatos), which are Endangered in the North East Atlantic, have been caught only exceptionally in the Bay of Biscay. This leaves a total of 28 species subject to concern according to IUCN (Table 3).
Among the species of concern in the Bay of Biscay, eight species (two Agnatha and six actynopterygian) are amphibiotic species, threatened by overfishing in both marine and freshwater habitats, alterations of freshwaters habitats and obstacles to migrations. The most critical situation is that of sturgeon (Acipenser sturio), threatened with extinction and included in Appendix I of the Convention on International Trade in Endangered Species of Wild Fauna and Flora (CITES). Eel (Anguilla anguilla) became recently a headline issue when it was included in CITES Appendix II (entered into force on 13 March 2009). Its decline was already mentioned as severe 20 years ago (de Beaufort and Lacaze 1987). The 20 strictly marine species are two small coastal species of seahorse, (Hippocampus spp.) threatened by habitat alterations, one seabream ( $\mathrm{Pa}$ grus pagrus), two large pelagic fish (albacore and swordfish, Xiphias gladius) and 16 Chondrichthyes which, in 2008, are not all in the Threatened categories of IUCN but were assessed 
as Threatened at least once in the past. The reasons for classifying Pagrus pagrus as Endangered by IUCN are unclear. This diagnosis was made for the Mediterranean Sea in 1996, but no record of a similar assessment in the Atlantic is available (C. Pollock, IUCN, personal communication). We are not aware of any major decline of $P$. pagrus in the North East Atlantic. On the other hand, the main fish stock reported to have collapsed in the Bay of Biscay over the last 30 years is the red seabream, Pagellus bogaraveo (Dardignac 1988), which would probably qualify for the Endangered category of IUCN. Confusion between $P$. bogaraveo and P. pagrus might be the explanation for the classification of the latter species.

Partly overlapping with IUCN data, Maurin (1994) provides an assessment for 17 fish species and de Beaufort and Lacaze (1987) for 15 species. Lastly, historical analyses by Quéro and Cendrero (1996) showed that large chondrichthyans were much more abundant in the $18^{\text {th }}$ century and represented a higher proportion of the total commercial catch. Bramble shark, Echinorhinus brucus, not caught by fisheries in recent years, was then very common, together with angelshark, Squatina squatina, and several rays. These authors stated that six species, including an actynopterygian of moderate size, were Endangered and six others were Vulnerable (Table 3) according to IUCN terminology. They expressed concern for a number of ray species but mentioned that the depletion of some species might be transient. Then, according to IUCN and other studies, 34 fish species might be considered to have qualified for the Threatened categories of IUCN, in the early 1990s. Fishing was the main threat for marine species but amphibiotic species were also impacted by terrestrial activities, which induce degradation of their freshwater habitats (Table 2). Lastly, we found no evidence of impact of mariculture at the reference time. However, the nematode Anguillicola crassus was introduce through mariculture and impacts eel population (Kirk 2003). As it applies to one species only with an unknown effect twenty years ago, we did not consider mariculture as impacting sensitive fish species in the early 1990s.

\section{Exploited species}

French landings statistics for the whole Bay of Biscay (Sub-area VIII) as reported to ICES include more than 200 taxonomic items, most being individual species and some aggregated categories. Landed species are fish, decapod crustaceans and molluscs. From 1973 to 1992, 38 categories made up 90\% of total landings. Ignoring four aggregated categories (marine fish, miscellaneous rays, molluscs, crabs), a list of 34 species was obtained.

Considering the exploited species in terms of stock assessment, conclusive assessments for the early 1990s were found for 20 stocks, some of which being uncertain (Table 4). Ten stocks were assessed as over exploited, 6 as fully exploited (including the cuckoo ray, Leucoraja naevus, which status could not be decided between under or fully exploited) and 4 as under exploited (Table 1). The status of the 14 remaining species in the early 1990s is unknown due to inconclusive assessments or no assessment at all. Assessments were also available for seven species with minor contributions to catches in the period 1973-92; among these, two were over exploited and the status of the five other could not be decided because information on trends in landings was not easy to interpret (Table 4).

The exploited fish species can be considered as impacted by fishing in the early 90s, as ten out of 20 assessed stocks were overexploited (Table 2). No comprehensive information on land-based or other recreational fishing for that period exists, but it seems likely that there were local impacts at the time (Table 2).

\section{Marine mammals}

Thirty-five species and one population of marine mammals may occur in the Bay of Biscay, most of which are only occasional visitors or rare vagrants. They were all assessed by IUCN by 1996. Three species were classified as Endangered, five were considered Vulnerable, nineteen were in the Lower Risk categories and data were insufficient for nine of them (Table 5). In addition, the right whale (Eubalaena glacialis glacialis) has probably gone extinct in the Bay of Biscay and in the North East Atlantic since the 1900s, and the gray whale Eschrichtius robustus has been extinct in the Atlantic probably from the 1700s (de Beaufort et Lacaze 1987; IUCN 2008). These two populations are not listed separately from other populations of the same species in the IUCN Red List. Nevertheless, this illustrates long-term human impacts on the ecosystem and on sensitive, once commercial, species. Of the nine marine mammals common in the Bay of Biscay, two species (grey seal, Halichoerus grypus and fin whale Balaenoptera physalus) were assessed as Endangered and two others (sperm whale, Physeter macrocephalus and harbour porpoise, Phocoena phocoena) as Vulnerable in the early 1990s. Incidental mortality in fishing gears may be a threat to marine mammals. In the 1980s and 1990s, driftnet and pelagic trawl fisheries induced bycatch of mammals. The trawl fishery with the highest bycatch rate was the sea bass pelagic trawl fishery. Common dolphin and white-sided dolphin, Lagenorhynchus acutus, were most commonly caught in this fishery (Morizur et al. 1999). To the west of Ireland and in the Bay of Biscay, mainly common dolphin, Delphinus delphis, and striped dolphin, Stenella coeruleoalba, were caught in the driftnet fishery for tuna, and preliminary estimates of the common dolphin incidental mortality in tuna fisheries showed that the inflicted mortality was sustainable (Fifas et al. 1998; Rogan and Mackey 2007). These three species were not in the Threatened categories of IUCN in 1996. The frequency of incidental catches of lesser abundant species might be by definition lower, but even the killing of small (possibly unobserved) numbers of individuals might be a problem in the case of Threatened species. For example, observations in the late 1990s suggest that driftnets induced some catch of sperm whale, a Vulnerable species (Rogan and Mackey 2007). In conclusion, the marine mammals ecosystem component can be considered as impacted by fishing in the Bay of Biscay in the early 1990s (Tables 1 and 2).

\section{Seabirds}

Nesting seabirds in the Bay of Biscay include European storm petrel (Hydrobates pelagicus), European shag 


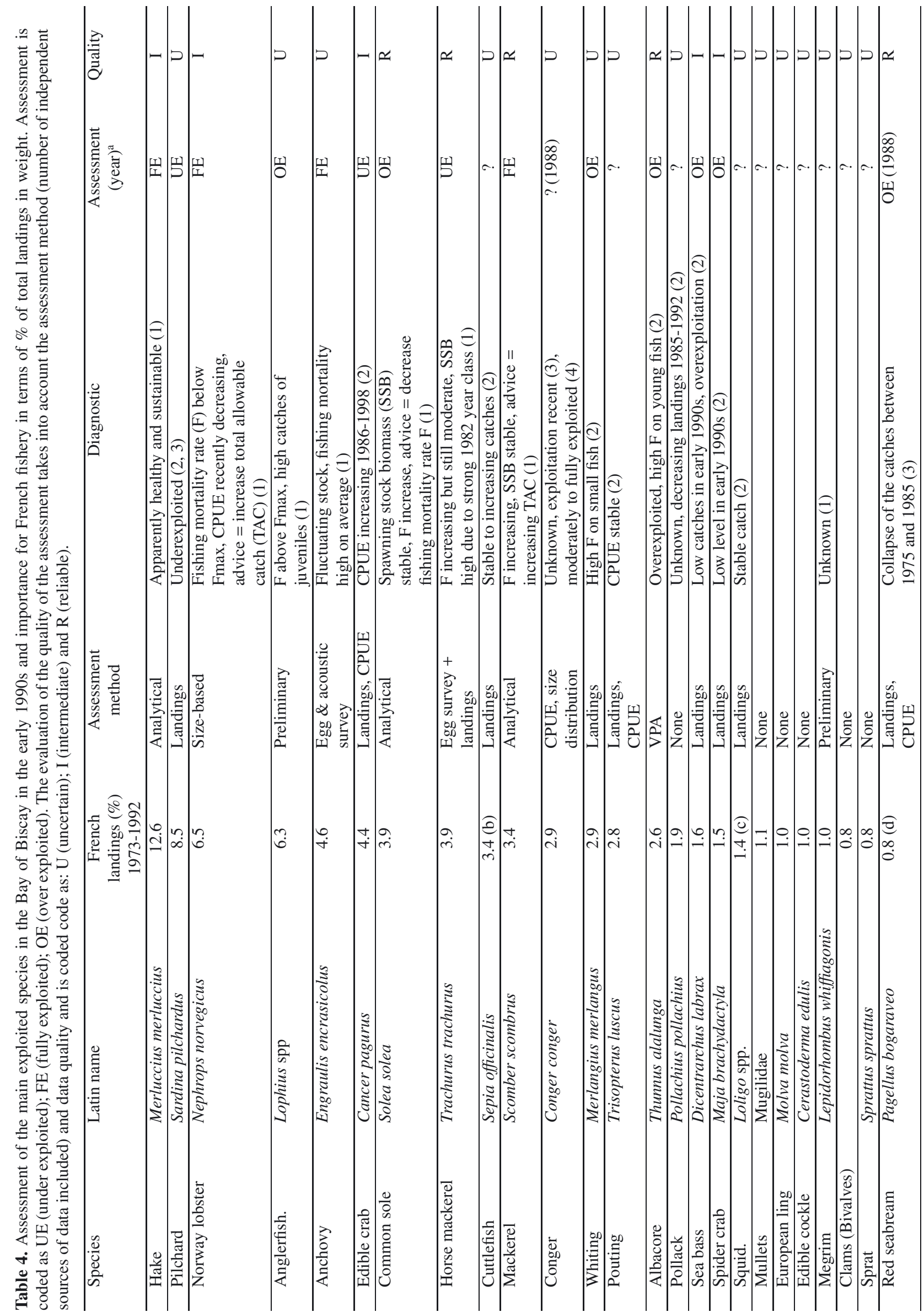




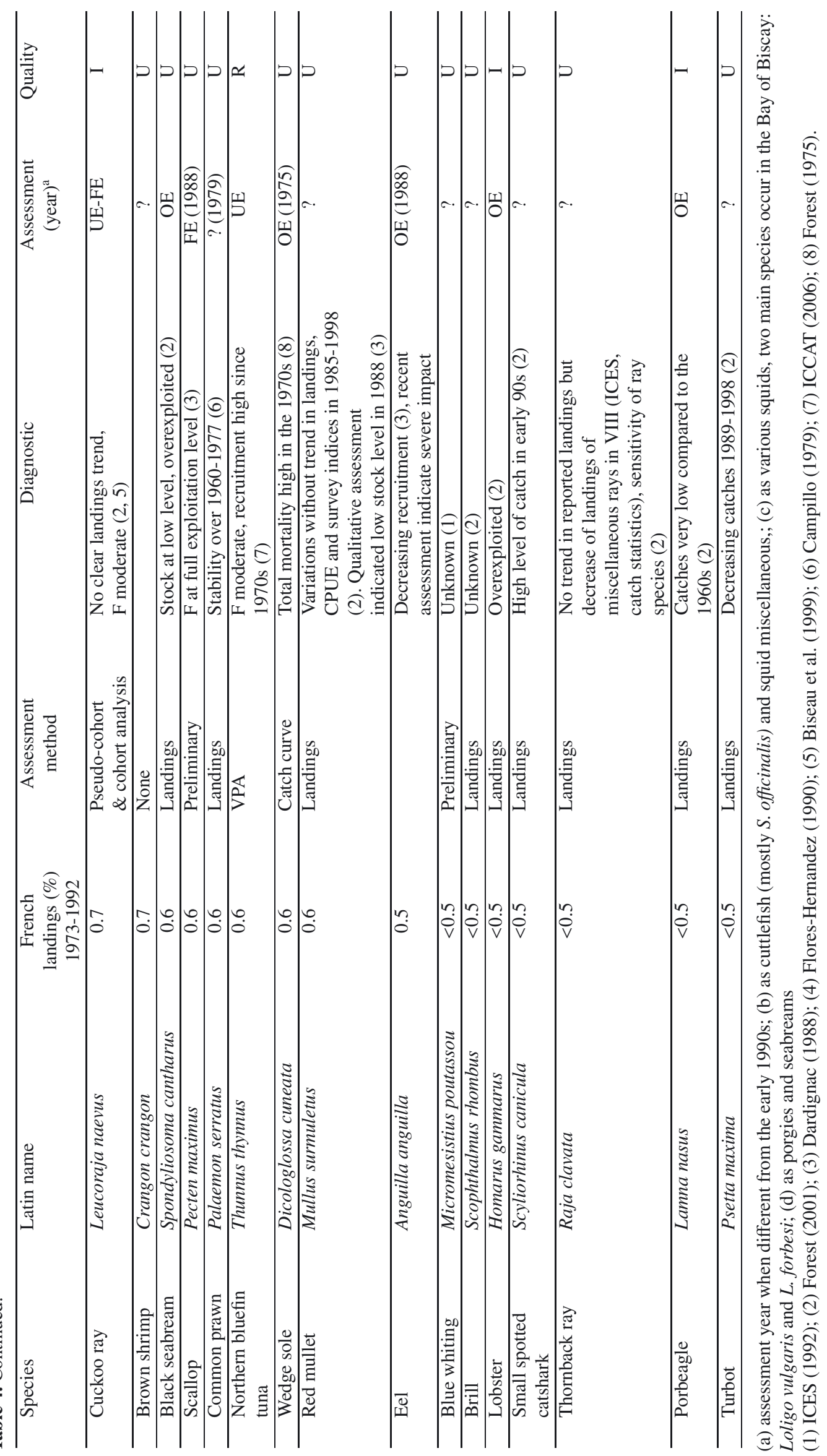


Table 5. Marine mammals from the North-East Atlantic, occurrences in the Bay of Biscay and assessed by IUCN in 1996 and current IUCN status. IUCN criteria: CR (critically endangered); EN (endangered); VU (vulnerable); LR (lower risk); LC (least concern); DD (data deficient). Classifications LR/nt (near threatened) and LR/lc (least concern) are from the IUCN 1994 Categories \& Criteria (version 2.3, see http://www.iucnredlist.org/static/categories_criteria).

\begin{tabular}{|c|c|c|c|c|}
\hline Species & Latin name & $\begin{array}{l}\text { Occurrence in the } \\
\text { Bay of Biscay (1) }\end{array}$ & $\begin{array}{l}1996 \text { IUCN } \\
\text { status (2) }\end{array}$ & $\begin{array}{l}2008 \text { IUCN } \\
\text { status (2) }\end{array}$ \\
\hline Ringed seal & Pusa hispida (Schreber, 1775) & $\mathrm{V}$ & LR/lc & $\mathrm{LC}$ \\
\hline Harbour seal & Phoca vitulina Linnaeus, 1758 & $\mathrm{R}(3)$ & LR/lc & $\mathrm{LC}$ \\
\hline Harp seal & $\begin{array}{l}\text { Pagophilus groenlandicus (Erxleben, } \\
1777 \text { ) }\end{array}$ & $\mathrm{V}$ & $\mathrm{LR} / \mathrm{lc}$ & $\mathrm{LC}$ \\
\hline Walrus & Odobenus rosmarus (Linnaeus, 1758) & $\mathrm{V}$ & $\mathrm{LR} / \mathrm{lc}$ & DD \\
\hline Grey seal & Halichoerus grypus (Fabricius, 1791) & $\mathrm{C}(3)$ & $\mathrm{EN}$ & $(5)$ \\
\hline Hooded seal & Cystophora cristata (Erxleben, 1777) & $\mathrm{V}$ & LR/lc & VU \\
\hline Cuvier's beaked whale & Ziphius cavirostris G. Cuvier, 1823 & $\mathrm{C}(4)$ & DD & $\mathrm{LC}$ \\
\hline Bottlenose dolphin & Tursiops truncatus (Montagu, 1821) & $\mathrm{C}$ & DD & $\mathrm{LC}$ \\
\hline $\begin{array}{l}\text { Rough-toothed dolphin } \\
1828 \text { ) }\end{array}$ & Steno bredanensis (G. Cuvier in Lesson, & $\mathrm{R}$ & DD & $\mathrm{LC}$ \\
\hline Atlantic spotted dolphin & Stenella frontalis (G. Cuvier, 1829) & $\mathrm{V} / \mathrm{A}$ & DD & DD \\
\hline Stripped dolphin & Stenella coeruleoalba (Meyen, 1833) & $\mathrm{C}$ & $\mathrm{LR} / \mathrm{cd}$ & $\mathrm{LC}$ \\
\hline False killer whale & Pseudorca crassidens (Owen, 1846) & $\overline{\mathrm{R}}$ & $\mathrm{LR} / \mathrm{lc}$ & $\overline{\mathrm{DD}}$ \\
\hline Sperm whale & Physeter macrocephalus Linnaeus, 1758 & $\mathrm{C}$ & VU & VU \\
\hline Harbour porpoise & Phocoena phocoena (Linnaeus, 1758) & $\mathrm{C}$ & VU & $\mathrm{LC}$ \\
\hline Killer whale & Orcinus orca (Linnaeus, 1758) & $\mathrm{R}$ & $\mathrm{LR} / \mathrm{cd}$ & DD \\
\hline Narwhal & Monodon monoceros Linnaeus, 1758 & $\mathrm{~V} / \mathrm{A}$ & DD & NT \\
\hline True's beaked whale & Mesoplodon mirus True, 1913 & $\mathrm{R}$ & $\mathrm{DD}$ & $\mathrm{DD}$ \\
\hline Blainville's beaked whale & $\begin{array}{l}\text { Mesoplodon densirostris (Blainville, } \\
\text { 1817) }\end{array}$ & $\mathrm{V} / \mathrm{A}$ & DD & DD \\
\hline Sowerby's beaked whale & Mesoplodon bidens (Sowerby, 1804) & $\mathrm{R}$ & DD & DD \\
\hline Humpback whale & $\begin{array}{l}\text { Megaptera novaeangliae (Borowski, } \\
\text { 1781) }\end{array}$ & $\mathrm{R}$ & VU & $\mathrm{LC}$ \\
\hline White-beaked dolphin & Lagenorhynchus albirostris (Gray, 1846) & $\mathrm{R}$ & LR/lc & $\mathrm{LC}$ \\
\hline $\begin{array}{l}\text { Atlantic white-sided } \\
\text { dolphin }\end{array}$ & Lagenorhynchus acutus (Gray, 1828) & $\bar{R}$ & $\mathrm{LR} / \mathrm{lc}$ & $\mathrm{LC}$ \\
\hline Dwarf sperm whale & Kogia sima (Owen, 1866) & V & LR/lc & DD \\
\hline Pygmy sperm whale & Kogia breviceps (Blainville, 1838) & $\bar{R}$ & $\mathrm{LR} / \mathrm{lc}$ & DD \\
\hline $\begin{array}{l}\text { North Atlantic bottlenose } \\
\text { whale }\end{array}$ & Hyperoodon ampullatus (Forster, 1770) & $\mathrm{R}$ & $\mathrm{LR} / \mathrm{cd}$ & $\mathrm{LC}$ \\
\hline Risso's dolphin & Grampus griseus (G. Cuvier, 1812) & $\mathrm{R}$ & DD & $\mathrm{LC}$ \\
\hline Long-finned pilot whale & Globicephala melas (Traill, 1809) & $\mathrm{C}$ & $\mathrm{LR} / \mathrm{lc}$ & $\mathrm{DD}$ \\
\hline Short-finned pilot whale & $\begin{array}{l}\text { Globicephala macrorhynchus Gray, } \\
1846\end{array}$ & $\overline{\mathrm{V}}$ & $\mathrm{LR} / \mathrm{cd}$ & $\mathrm{DD}$ \\
\hline Common dolphin & Delphinus delphis Linnaeus, 1758 & $\mathrm{C}$ & $\mathrm{LR} / \mathrm{lc}$ & $\mathrm{LC}$ \\
\hline $\begin{array}{l}\text { Long-beaked common } \\
\text { dolphin }\end{array}$ & Delphinus capensis Gray, 1828 & $\mathrm{~V} / \mathrm{A}$ & $\mathrm{LR} / \mathrm{lc}$ & DD \\
\hline Beluga & Delphinapterus leucas (Pallas, 1776) & $\mathrm{V} / \mathrm{A}$ & VU & NT \\
\hline Fin whale & Balaenoptera physalus (Linnaeus, 1758) & $\mathrm{C}(4)$ & EN & EN \\
\hline Blue whale & $\begin{array}{l}\text { Balaenoptera musculus musculus } \\
\text { (Linnaeus, 1758) }\end{array}$ & $?$ & VU & (5) \\
\hline Sei whale & Balaenoptera borealis Lesson, 1828 & $?$ & EN & EN \\
\hline Common minke whale & $\begin{array}{l}\text { Balaenoptera acutorostrata Lacepède, } \\
1804\end{array}$ & $?$ & $\mathrm{LR} / \mathrm{nt}$ & $\mathrm{LC}$ \\
\hline Bowhead whale & Balaena mysticetus Linnaeus, 1758 & $?$ & $\mathrm{LR} / \mathrm{cd}$ & $\mathrm{LC}$ \\
\hline
\end{tabular}

(1): C: Common; R: Rare; V: Vagrant individuals; A: absent; ? unknown.

(2) Assessments in the 1990s and in the 2000s were carried out under slightly different classification schemes (http://www.iucnredlist.org/static/categories_criteria).

(3) Mainly to the North of the area; (4) in oceanic waters only; (5) under assessment. 
Table 6. Marine turtles occurring in the Bay of Biscay and assessed by IUCN, 1990 and current status. IUCN criteria: CR (critically endangered); EN (endangered); VU (vulnerable); LC (least concern).

\begin{tabular}{llccc}
\hline Species & Latin name & $\begin{array}{c}\text { Occurrence in the } \\
\text { Bay of Biscay }{ }^{(1)}\end{array}$ & 1990 IUCN status & $\begin{array}{c}\text { 2008 IUCN status } \\
\text { (year of assessment) }\end{array}$ \\
\hline Loggerhead & Caretta caretta (Linnaeus, 1758) & C & VU & EN (1996) \\
Hawksbill Turtle & Eretmochelys imbricata (Linnaeus, 1766) & V & EN & CR (2008) \\
Leatherback & Dermochelys coriacea (Vandelli, 1761) & C & EN & CR (2000) \\
Green Turtle & Chelonia mydas (Linnaeus, 1758) & V & EN & EN (2004) \\
Atlantic Ridley & Lepidochelys kempii (Garman, 1880) & V & EN & CR (1996) \\
\hline
\end{tabular}

(1) C: Common; V: Vagrant individuals.

(Phalacrocorax aristotelis), herring gull (Larus argentatus), laughing gull (Larus atricilla), yellow-legged gull (Larus michahellis), lesser black-backed gull (Larus fuscus), kittiwake (Rissa tridactyla) and common guillemot (Uria aalge). The most abundant species are northern gannet (Morus bassanus), gulls (seven Larus species), Balearic shearwater (Puffinus mauretanicus), sooty shearwater (Puffinus griseus), Cory's shearwater (Calonectris diomedea), razorbill (Alca torda) and Atlantic puffin (Fratercula arctica).

For de Beaufort and Lacaze (1987), two seabirds occurring in the Bay of Biscay, the Manx shearwater (Puffinus puffinus) and the European storm petrel, are threatened species. Only European storm petrel is known with certainty to have nested in the Bay of Biscay; its abundance in southern Bay of Biscay decreased during 1976-85 (de Beaufort and Lacaze 1987; Maurin 1994). Maurin (1994) classified them as Vulnerable but they were classified as Lower Risk by IUCN in 1998 due to large breeding areas and high population numbers. Lastly, the Balearic shearwater was classified as Critically Endangered by IUCN in 2000 due to several threats, occurring mainly within its small breeding range in the Balearic Islands, resulting in a rapid population decline (IUCN 2008). The Balearic shearwater is therefore the only Threatened marine seabird occurring in the Bay of Biscay, which might not be an essential habitat to the species, nor the area where threats occur. Hence, the Bay of Biscay does not seem to be an area where management is crucial to seabird conservation. The coast of southern Brittany is, however, important to at least eight nesting seabird species (Cadiou 2002). The only clear indication of significant problems at the reference time is the impact of oil pollution (Cadiou 2002) (Tables 1 and 2). Nevertheless, some populations may have been at low levels due to threats (mainly habitat loss) in other areas (Oro and Martinez-Abrain 2007). Artificial food resources from rubbish tips and fishery discards have benefited to some populations (Pons and Migot 1995) but this does not seem to be the main problem to threatened seabird species (Oro and Martinez-Abrain 2007).

\section{Sea turtles}

The loggerhead and the leatherback turtles are frequently sighted in the Bay of Biscay. Individuals of three other species (Table 6) may be rare vagrants on their long-distance migrations using the Gulf Stream (de Beaufort and Lacaze 1987). No species is known to have spawned on the Bay of Biscay coast.
Bycatch of sea turtles in driftnets in the Bay of Biscay has been reported, a proportion of which being possibly released alive (Antoine 1990; Rogan and Mackey 2007). Leatherback occurs in the Pertuis Breton and Antioche (Fig. 1) where they feed upon jellyfish (Rhizostoma pulmo). Debris of plastic bags, recognized as a threat to leatherback, are abundant in these areas (Duguy et al. 1998; Duron et al. 1983; Galgani et al. 1995) (Table 1). In the early 1990s, all sea turtles were in the Threatened categories of IUCN worldwide. They still are nowadays, except one for which data are deficient. The five species occurring in the Atlantic are all Threatened (Table 6). The Bay of Biscay represents only a minor part of their large distribution and is not a spawning area, so that the main threats to sea turtles probably occur elsewhere. Nevertheless, local impacts on sea turtles are mainly due to fishing and debris of plastic bags and are likely to have already existed in the early 1990s (Table 2).

\section{Discussion}

In this study, we attempted to inventory all data available about the Bay of Biscay ecosystem in the early 1990s. The amount of available information was clearly contrasted over ecological components, the vertebrates component being by far the most studied. We aimed at tracing back most data and information that was previously used at the regional scale of the Bay of Biscay, however, we cannot claim to have found all data, in particular some small scale studies, that may still convey some information for the Bay of Biscay, might have been missed, in particular when they remained unpublished. The main results from this inventory (situation of overfishing and significant impact of human activities on coastal and estuarine habitats, see below) are in line with the common knowledge in the Bay of Biscay and other areas and drive the on-going move towards ecosystem-based management.

We described the Bay of Biscay ecosystem by a component tree with six main branches. The structure of the tree and the variable number of components by branch reflect the purpose of this work, which is assess the ecological status, which is neither a good nor pristine status, some time in the past in support of the management of human activities. Component trees created for other purposes might well have a different structure, address different spatial scale (e.g. identifying every estuary as a component of the bay of Biscay ecosystem) or put emphasis on the whole social-ecological system. Human activities were regarded here as pressures and most components of the 
Bay of Biscay ecosystem were impacted. In the early 1990s, mariculture, sand and gravel extraction and waste dumping had local impacts only. Fishing transport and diverse terrestrial activities were documented to have impacted six, one and eight ecosystem components out of the 19 assessed. Impacts of maritime transportation were poorly known. However, two subsequent oil spills, in 1999 and 2002, had important consequences for the ecosystem ${ }^{3}$. In the 2000 s, several ships were seized by French authorities for (possibly deliberate) pollution, and it is quite obvious that merchant ships released litter and liquid contaminants (e.g. waste oil) at sea in the past, and this may have impacted several components although we found no systematic record of it. Impacts of mariculture might be local and have been clearly demonstrated for several environmental features and benthic communities. Overall, 37 out of 114 component-activity cells were found to have been impacted by one or several of the six human activity categories considered. For 23 of these, there was documented evidence; for the others the impact was considered possible.

It was not always easy to ascertain the impact of a given human activity on an ecosystem component owing to lack of knowledge or, in certain cases, clear impact criteria. Limited data for biotic components other than vertebrates may induce bias in the conclusions and may prevent to understand processes driving changes in the ecosystem. For example, there exists general knowledge on species composition and abundance of plankton and, based upon ecosystem models, the primary production was estimated back to 1970s (Huret et al. 2009) but there are no time series of observations and modelbased estimations may be sensitive to model assumptions. Temporal variations of species composition of both phyto- and zooplankton are not known in the Bay of Biscay but have occurred in other areas with some effects on fish (Beaugrand 2005; Pitois and Fox 2006). The role of benthic invertebrates in ecosystem functioning is greatly recognised and the benthos "cover" may be important to fish (Caddy 2008). Nevertheless, benthos and invertebrates are seldom inventoried, monitored and managed (Rohr et al. 2006; Brind'Amour et al. 2009). In the Bay of Biscay, sampling of benthos was carried out only on two occasions and did not cover the whole area. Similarly, at the other end of the trophic web, there are no time series of abundance of marine mammals and some pressures may be poorly known, e.g. seabird mortality in fishing gears (Zydelis et al. 2009). As driftnet fishing was regulated from 1998 and banned from 2002 to protect marine mammals, the pressure on mammals that we identified for the early 1990s probably decreased in recent years (Rogan and Mackey 2007). Coastal waters and habitats can be considered as chemically impacted by human activities, with little or no values above recommended thresholds. Long-term declining trends in most contamination levels suggest improvement of the habitat quality since the reference time, but time series are insufficient for some recently identified toxic substances (Beliaeff et al. 2005).

Among the commercial species for which stock assessments were available, half were over exploited at the reference time. The criteria for assessing the state of stocks and the objectives of fisheries management have changed over time

\footnotetext{
3 See, for example, the special issue on Erika oil spill in Aquatic Living Resources $2004,17, \mathrm{~N}^{\circ} 3$.
}

and we did not revisit the state of these stocks based upon the current nor possible future management objectives (e.g. restoring stocks to Maximum Sustainable Yield). Nevertheless, the proportion of the over exploited stocks makes it clear that the situation in the early 1990s was one of chronic over exploitation and it is not known to have improved since. Further, the Bay of Biscay fish community was found to include 34 species, eight of which being amphidromous, qualifying for the Threatened categories of IUCN although a much smaller set was assessed so by IUCN. Most of these species are large Chondrichthyes and several of them were of commercial importance in the past. One finfish species, the red seabream (Pagellus bogaraveo) was one of the 4-5 top ranking species in French landings from the Bay of Biscay up to the 1970s. Note that, like four other species (albacore, Thunnus alalunga, eel Anguilla anguilla, thornback ray, Raja clavata, and porbeagle, Lamna nasus) red seabream was considered both as an exploited stock and a sensitive species in our assessment, therefore double counting impacts.

Unlike mammals, which were all assessed by IUCN criteria in 1996, all fish species have not yet been assessed. However, we considered that the list of threatened species from de Beaufort and Lacaze (1987) was reliable for fish species, as these authors included experts of the fish fauna for the Bay of Biscay. Eight large Chondrichthyes were severely depleted in the late 1980s and remained so during the 1990s. Other threatened species were amphidromous species suffering a combined impact of fisheries and habitat loss and one coastal seahorse suffering habitat destruction (although we did not go back to the underlying data). Although some threatened seabirds and sea turtles occur in the Bay of Biscay, it does not seem to be an area where significant impacts take place, except for leatherback turtles that may be harmed by plastic debris when feeding on the Bay of Biscay coast.

So far, two whale species previously occurring in the Bay of Biscay are reported as extinct at population level; this reflects the overhunting of cetaceans in the past. There is no other reported extinction in the Bay of Biscay but extinction reports may lag several decades behind the actual extinction time (Dulvy et al. 2005).

Finally, for certain components, no commonly agreed impact criteria exist, as they do, for example, for threatened or exploited species. In these cases, an impact was identified when the component clearly changed between the 1950s and the 1980s, due to human activities. This is a recognition that the human activities concerned had detectable consequences on the composition and/or functioning of the component but does not imply anything regarding the sustainability of the related pressure level. Future research is therefore required to determine clear impact criteria for all ecosystem components.

Expectedly, our reference state suggests that the main problem in the Bay of Biscay ecosystem in the early 1990s was overfishing. Since the early 1990s, the state of some stocks may have changed over time, e.g. the stock of hake have decreased in the early 2000s and is in a better condition now while others like anchovy, might have been affected by environmental factors (Borja et al. 2008); no threaten fish population is known to have rebuilt and time series or fishery indicators suggest neither populations nor the community have 
improved (Rochet et al. 2005). Therefore, the broad-brush situation from the early 1990s has remained about the same over the past two decades. Far from being specific to the Bay of Biscay, this situation is general to European waters and many other world marine areas. In European waters, the problems of overfishing, overcapacity and subsidies have been addressed by fishery management through introduction of (i) TACs for more commercial stocks and diverse technical measures, (ii) decommissioning plans to reduce fishing fleets capacities and (iii) strong regulations of subsidies introduced in the last Common Fishery Policy (CFP) reform in 2002. Nevertheless, the CFP has not worked well to prevent these problems and their consequences: low economic resilience, decline in the volume of fish caught by European fishers (European Commission 2009) and impacts on several ecosystem components, described in this paper. The CFP is now being integrated into an ecosystem based management of Marine ecosystem under the umbrella of the MSFD and should aim at achieving objectives defined at global level such as exploiting resources at MSY level. A "vision for European fisheries by 2020" given in the CFP reform green paper (European Union 2009) highlights the desirable state of the human fishery system and exploited resources that should drive the political will and stakeholders engagement towards a policy for ecologically sustainable and economically profitable fisheries.

In the MSFD, populations and communities exploited by fishing are part of the initial assessment required by 2012 . Assessing a reference state in the past, i.e. 20 years before the requested 2012 initial assessment, might help to account for temporal variations. In other words, time series of indicators might allow assessing not only the initial state but also the current direction (improving/deteriorating with respect to a desirable state) and the type of natural fluctuations for each ecosystem component. For example, for some fish populations we might be able to characterize whether they display large or small variations in abundance over time due to the variability of recruitment and therefore account for the range of natural variability in the 2012 initial assessment.

In addition to the need for better fishery governance, the inventory of pressures on several ecological components from all other human activities stressed the need for the implementation of the ecosystem-based approach of the management of marine areas. The mostly local but numerous pressures, from activities other than fishing, are concentrated in estuarine and costal habitats and their biological components (macrophytes, coastal benthos), so that the integrity and function of these coastal systems should be central to future governance.

Therefore our inventory suggests that vertebrates as well as estuarine and coastal habitat might be central to monitoring programmes and programmes of measures to be implemented in application of the MSFD. We also identified some data gaps in particular for micro-organisms, sedimentary substrate and benthos for which monitoring at reasonable costs might be possible. However, definition of relevant spatio-temporal scales, methods for monitoring of, so far, poorly observed components are beyond the scope of our study.

Lastly, we only mentioned global climate change in the context of temperature; observed values in the early 1990s were still in the range of centennial fluctuations. Global climatic change might however be a major driver of ecosystem functions, diversity and production in the long term not only through a direct effect of temperature but also due to changes in oceanic circulation, stratification and acidification. As a result defining a desirable state for ecosystems is not an easy task. This desirable state, or good environmental status, should primarily be an improvement compared to our reference state but it will be a moving target, in particular in terms of living resources owing to the impact of global change on the carrying capacity at all organisational levels of the ecosystem.

Acknowledgements. This study was carried out with financial support from the Biodiversity project ANR-IFB 2005 "Global change, dynamics of exploited marine biodiversity, and viability of fisheries (CHALOUPE)" and the EC-funded research project FP6 - 044227 "Indicators for fisheries Management in Europe (IMAGE)". We are grateful to Serge Garcia for constructive comments on a previous version of the manuscript and to Hélène Oger-Jeanneret, Benoit Mesnil and André Forest for comments and complements to our review.

\section{References}

Abbes R., 1991, Atlas des pêches françaises dans les eaux européennes. Rennes, IFREMER - Editions Ouest-France.

Abril G., Etcheber H., Le Hir P., Bassoullet P., Boutier B., Frankignoulle M., 1999, Oxic/anoxic oscillations and organic carbon mineralization in an estuarine maximum turbidity zone (The Gironde, France). Limnol. Oceanogr. 44, 1304-1315.

Abril G., Etcheber H., Delille B., Frankignoulle M., Borges A.V., 2003, Carbonate dissolution in the turbid and eutrophic Loire estuary. Mar. Ecol. Prog. Ser. 259, 129-138.

Altuna A., 2007, Bathymetric distribution patterns and biodiversity of benthic Medusozoa (Cnidaria) in the Bay of Biscay (northeastern Atlantic). J. Mar. Biol. Assoc. UK 87, 681-694.

Alzieu C., 1998, Tributyltin: case study of a chronic contaminant in the coastal environment. Ocean Coast. Manage. 40, 23-36.

Alzieu C., 1999, Dragage et environnement marin, état des connaissances. Ifremer, Brest.

Alzieu C., 2000, Environmental impact of TBT: the French experience. Sci. Total Environ. 258, 99-102.

Antoine L., 1990, Des dauphins, des thons et des pêcheurs, le filet maillant en Atlantique Nord. Equinoxe 33, 11-14.

Arleny I., Tabouret H., Rodriguez-Gonzalez P., Bareille G., Donard O.F.X., Amouroux D., 2007, Methylmercury bioconcentration in muscle tissue of the European eel (Anguilla anguilla) from the Adour estuary (Bay of Biscay, France). Mar. Pollut. Bull. 54, 1031-1036.

Arzel P., 1998, Les laminaires sur les côtes bretonnes, évolution de l'exploitation et de la flottille de pêche, état actuel et perspectives. Brest, Ifremer.

Auby I., Bachelet G., Labourg P.J., 1993, Biomass and species composition of macrophytes in Arcachon Bay and Prévost lagoon, with a compilation of data on primary production in Arcachon Bay. CLEAN (Coastal lagoon eutrophication and anaerobic processes). Progr. Rep. pp. 65-72.

Belleudy P., 2000, Restoring flow capacity in the Loire River bed. Hydrol. Process. 14, 2331-2344.

Beliaeff B., Grouhel A., Billen A., Barnouin B., 2005, Vingt cinq ans d'observations de la qualité des eaux littorales: tendances de dégradation et d'amélioration. La Houille Blanche 3, 69-80. 
Belin C., Raffin B., 1998, Les espèces phytoplanctoniques toxiques et nuisibles sur le littoral français de 1984 à 1995, résultats du REPHY (Réseau de surveillance du phytoplancton et des phycotoxines). RST.DEL/MP-AO 98-16, Ifremer.

Bergmann M., Wieczorek S.K., Moore P.G., Atkinson R.J.A., 2002, Utilisation of invertebrates discarded from the Nephrops fishery by variously selective benthic scavengers in the west of Scotland. Mar. Ecol. Prog. Ser. 233, 185-198.

Beaugrand G., 2005, Monitoring pelagic ecosystems using plankton indicators. ICES J. Mar. Sci. 62, 333-338.

Binet D., 1999, Les pêches côtières de la baie du Mont-Saint-Michel à la baie de Bourgneuf au début du XIX ${ }^{\mathrm{e}}$ siècle. Ifremer, Brest.

Blanchard F., 2001, Une approche de la dynamique des peuplements de poissons démersaux exploités: analyse comparée de la diversité spécifique dans le golfe de Gascogne (océan Atlantique) et dans le golfe du Lion (mer Méditerranée). Aquat. Living Resour. $14,29-40$.

Blanchard F., LeLoc' h F., Hily C., Boucher J., 2004, Fishing effects on diversity, size and community structure of the benthic invertebrate and fish megafauna on the Bay of Biscay coast of France. Mar. Ecol. Prog. Ser. 280, 249-260.

Blanchard F., Vandermeirsch F., 2005, Warming and exponential abundance increase of the subtropical fish Capros aper in the Bay of Biscay (1973-2002). C. R. Biol. 328, 505-509.

Borja A., Fontan A., Saenz J., Valencia, V., 2008, Climate, oceanography, and recruitment: the case of the Bay of Biscay anchovy (Engraulis encrasicholus), Fish. Oceanogr. 17, 477-493.

Bourcereau E., Daurès F., Girard S., Guyader O., Kalaydjian R., Thébaud O., 2000, Données économiques maritimes françaises 1999. Ifremer, Brest.

Bourillet J.-F., Folliot B., Lesueur P., Goubert E., 2004, Architecture des sédiments holocènes de la plate- forme armoricaine et lien avec l'eustatisme. In: Les incisions et dépôts de la marge atlantique française depuis le néogène, états des lieux, Paris, 25-26 novembre 2004. SGF-ASF ed., Paris.

Bourillet J-F., Jouanneau J-M., Macher C., Le Hir P., Naughton F., 2006, "La Grande Vasière" mid-shelf mud belt: Holocene sedimentary structure, natural and anthropogenic impacts. Proc. $10^{\text {th }}$ Int. Symp. Oceanography of the Bay of Biscay, Vigo, Spain, April 19-21, 2006, pp. 131-134. (http://www.ifremer.fr/docelec/).

Brind'Amour A., 2007, Functional diversity: a study on the Bay of Biscay nursery habitats. ICES Annual Science Conference. International Council for the Exploration of the Sea, Helsinki. Conf. Proc. ICES CM2007/E19.

Brind'Amour A., Rouyer A., Martin J., 2009, Functional gains of including non-commercial epibenthic taxa in coastal beam trawl surveys: a Note. Cont. Shelf Res. 29, 1189-1194.

Caddy J.F., 2008, The importance of "cover" in the life histories of demersal and benthic marine resources: a neglected issue in fisheries assessment and management. Bull. Mar. Sci. 83, 7-52.

Cadiou B., 2002, Les oiseaux marins nicheurs de Bretagne. Cah. Nat. Bretagne.

Campillo A., 1979, Contribution à l'étude de la crevette rose Palaemon serratus (Pennant) Exploitation - Biologie - Elevage - Epidémiologie, Univ. Sci. Techn. Languedoc, Montpellier (http://www.ifremer.fr/docelec/).

Chapelle A., 1990, Modélisation d'un écosystème marin côtier soumis à l'eutrophisation: la baie de Vilaine (sud-Bretagne). Etude du phytoplancton et du bilan en oxygène. Thèse Univ. Paris VI.

Clynick B.G., McKindsey C.W., Archambault P., 2008, Distribution and productivity of fish and macroinvertebrates in mussel aquaculture sites in the Magdalen Islands (Quebec, Canada). Aquaculture 283, 203-210.
Courrat A., Lobry J., Nicolas D., Laffargue P., Amara R., Lepage M., Girardin M., Le Pape O., 2009, Anthropogenic disturbance on nursery function of estuarine areas for marine species. Estuar. Coast. Shelf Sci. 81, 179-190.

Dardignac J., 1988, Les pêcheries du golfe de Gascogne. Bilan des connaissances. Rapp. Scient. Techn. 9, IFREMER Editions, Paris.

D'Elbée J., 2001, Distribution et diversité des copépodes planctoniques dans le golfe de Gascogne. In: D'Elbée J., Prouzet P. (Eds) Océanographie du golfe de Gascogne. VII ${ }^{\mathrm{ème}}$ colloque international, Biarritz. pp. 147-156.

de Beaufort F., Lacaze J.-C., 1987, Livre rouge des espèces menacées en France, tome 2, Espèces marines et littorales menacées. Secrétariat de la faune et de la flore, MNHN, Paris.

Decamps P., Léauté, J.P., 1988, Flottilles et pêches maritimes du sud du golfe de Gascogne dans les quartiers de Noirmoutier à Bayonne en 1986. Rapp. Scient. Techn. 13, Brest, IFREMER.

de Montaudouin X, Sauriau P.-G., 2000, Contribution to a synopsis of marine species richness in the Pertuis charentais Sea with new insights in soft-bottom macrofauna of the Marennes-Oléron Bay. Cah. Biol. Mar. 41, 181-222.

de Madron X.D., Ferre B., Le Corre G., Grenz C., Conan P., Pujo-Pay M., Buscail R., Bodiot O., 2005, Trawling-induced resuspension and dispersal of muddy sediments and dissolved elements in the Gulf of Lion (NW Mediterranean). Cont. Shelf Res. 25, 19-20, 2387-2409.

Désaunay Y., Pérodou J.-B., Beillois P., 1981, Etude des nurseries de poissons du littoral de la Loire Atlantique. Science Pêche 319, $1-23$.

Désaunay Y., Martin J., Lobry J., Laffargue P., 2006, Restriction des habitats de nourriceries par les espèces invasives et/ou proliférantes: vasières à Haploops et fonds à crépidules. Rapp. interne Nantes, Ifremer.

Dubrulle C., Jouanneau J.M., Lesueur P., Bourillet J.F., Weber, O., 2007, Nature and rates of fine-sedimentation on a mid-shelf: "La Grande Vasière" (Bay of Biscay, France). Cont. Shelf Res. 27, 2099-2115.

Duguy R., Moriniere P., Le Milinaire C., 1998, Factors of mortality of marine turtles in the Bay of Biscay. Oceanol. Acta 21, 383-388.

Dulvy N.K., Jennings S., Goodwin N.B., Grant A., Reynolds J.D., 2005, Comparison of threat and exploitation status in North-East Atlantic marine populations. J. Appl. Ecol. 42, 883-891.

Duron M., Quéro J.-C., Duron P., 1983, Présence dans les eaux côtières de France et de Guyane fréquentées par Dermochelys coriacea $\mathrm{L}$. de Remora remora L. et de Rhizostoma pulmo L. Ann. Soc. Sci. Nat. Charente-Marit. 7, 147-151.

European Union, 2008, Directive 2008/56/EC of the European parliament and of the Council of 17 June 2008, establishing a framework for community action in the field of marine environmental policy (Marine Strategy Directive). Official Journal of the European Union, 25 June 2008, L164, 19-40.

European Commission, 2009, Green paper, reform of the common fisheries policy. Brussels 22 April 2009 com. 163 Final Rep.

Ferre B., de Madron X.D., Estournel C., Ulses C., Le Corre G., 2008, Impact of natural (waves and currents) and anthropogenic (trawl) resuspension on the export of particulate matter to the open ocean Application to the Gulf of Lion (NW Mediterranean). Cont. Shelf Res. 28, 2071-2091.

Fifas S., Goujon M., Antoine L., 1998, Application of Leslie's model on a population of common dolphin (Delphinus delphis): sensitivity study. Aquat. Living Resour. 11, 359-369.

Fletcher W.J., 2005, The application of qualitative risk assessment methodology to prioritize issues for fisheries management. ICES J. Mar. Sci. 62, 1576-1587. 
Forest A., 1975, Le céteau Dicologoglossa cuneata (Moreau), sa biologie et sa pêche dans le sud du golfe de Gasgogne. Rev. Trav. Inst. Pêches Marit. 39, 5-62.

Forest A., 2001, Ressources halieutiques hors quotas du Nord Est Atlantique: bilan des connaissances et analyse de scénarios d'évolution de la gestion. Plouzané, Ifremer, Dir. Ressources vivantes, Dép. Ressources halieutiques.

Flores-Hernandez D., 1990, Les pêcheries de congre (Conger conger L.) dans le Mor Braz, Bretagne sud (élements de la biologie et de gestion de la ressource). Thesis, Univ. Aix-Marseille II.

Galgani F., Burgeot T., Bocquéné G., Vincent F., Léauté J.-P., Labastie J., Forest A., Guichet R., 1995, Distribution and abundance of debris on the continental shelf of the Bay of Biscay and in Seine Bay. Mar. Pollut. Bull. 30, 58-62.

Galgani F., Léauté J.-P., Moguedet P., Souplet A., Verin Y., Carpentier A., Goraguer H., Latrouite D., Andral B., Cadiou Y., Mahé J.C., Poulard J.C., Nérisson P., 2000, Litter on the sea floor along European coasts. Mar. Pollut. Bull. 40, 516-527.

Gilliers C., Le Pape O., Desaunay Y., Morin J., Guérault D., Amara R., 2006, Are growth and density quantitative indicators of essential fish habitat quality? An application to the common sole Solea solea nursery grounds. Estuar. Coast. Shelf Sci. 69, 96-106.

GIP Loire estuaire, 2007. Les dragages d'entretien dans l'estuaire, Cah. indicateurs 1, Nov. 2007.

Glémarec M., 1969, Les peuplements benthiques du plateau continental Nord-Gascogne. Ph.D. thesis, Univ. Bretagne occidentale, Brest.

Glémarec M., 1971, Benthic stocks of the continental shelf of North Gascogne (France). Thesis Fac. Sci., Paris (summary). Bull. Soc. Ecol. 2, 345-346.

Gohin F., Lampert L., Guillaud J.F., Herbland A., Nezan E., 2003, Satellite and in situ observations of a late winter phytoplankton bloom, in the northern Bay of Biscay. Cont. Shelf Res. 23, 1117 1141.

Gohin F., Loyer S., Lunven M., Labry C., Froidefond J.M., Delmas D., Huret M., Herbland A., 2005, Satellite-derived parameters for biological modelling in coastal waters: Illustration over the eastern continental shelf of the Bay of Biscay. Remote Sens. Environ. 95, 29-46.

Grall J., 2003, Fiche de synthèse sur les biocénoses: les bancs de maërl. IUEM(UBO)/LEMAR (http://www.rebent.org/documents/)

Grall J., Le Loc'h F., Guyonnet B., Riera P., 2006, Community structure and food web based on stable isotopes ( $\mathrm{N}$ and $\mathrm{C}$ ) analysis of a North Eastern Atlantic maerl bed. J. Exp. Mar. Biol. Ecol. 338, $1-15$.

Gruet Y., 1989, Algues des côtes rocheuses de Loire-Atlantique et de Vendée: richesses naturelles du littoral. Bull. Soc. Sci. Nat. Ouest de la France.

Gruet J., Héral M., Robert J.M., 1976, Premières observations sur l'introduction de la faune associée au naissain d'huîtres japonaises Crassostrea gigas (Thunberg), importé sur la côte atlantique française. Cah. Biol. Mar. 17, 173-184.

Guérault D., Dorel D., Désaunay Y., 1996, Cartographie des nourriceries littorales de poissons du golfe de Gascogne. Plouzané, Ifremer.

Guichet R., Moguedet P., Mesnil B., Battaglia A., 1998, Echantillonnage biologique des rejets de poissons et autres organismes dans le Golfe de Gascogne. Rapp. final Contrat BIO ECO 94 - 054 CEE DG XIV, Ifremer.

Hall S.J., 1999, The effects of fishing on marine ecosystems and communities. Blackwell Science.
Héral M., Berthomé J.-P., 1991, Water quality criteria and monitoring for marine mollusc culture: the French experience. In: De Pauw N., Joyce J. (Eds). Eur. Aquac. Soc. Spec. Publ. 16, Gent, Belgium, pp. 177-190 (http://www.ifremer.fr/docelec/)

Hily C., 2006, Fiche de synthèse sur les biocénoses: Les herbiers de zostères marines (Zostera marina et Zostera noltii), IUEM(UBO)/LEMAR, CNRS UMR 6539, Brest (http://www.rebent.org/documents/)

Hily C., Le Loc'h F., Grall J., Glémarec M., 2008, Soft bottom macrobenthic communities of North Biscay revisited: long-term evolution under fisheries-climate forcing. Estuar. Coast. Shelf Sci. 78, 413-425.

Huret M., Gohin F., Delmas D., Lunven M., Garcon V., 2007, Use of SeaWiFS data for light availability and parameter estimation of a phytoplankton production model of the Bay of Biscay. J. Mar. Syst. 65, 509-531.

Huret M., Struski C., Léger F., Petitgas P., Lazure P., Sourisseau M., 2009, Modélisation couplée physique-biogéochimie du golfe de Gascogne sur la période 1971-2007. Ifremer.DOP/EMH/2009.01. (http://www.ifremer.fr/docelec/)

ICCAT, 2006, Report of the 2006 Atlantic Bluefin Tuna Stock Assessment Session, Madrid, 12-18 June 2006. SCRS /2006/013 (http://www.iccat.int/)

ICES, 1992, Reports of the ICES Advisory Committee on Fishery Management 1991. ICES Coop. Res. Rep. 179 (http://www.ices.dk)

ICES, 2001, Report of the ICES Working Group on the Effects of Extraction of Marine Sediments on the Marine Ecosystem. ICES Coop. Res. Rep. 247.

ICES, 2007, Report of the Working Group on Ecosystem Effects of Fishing Activities (WGECO). ICES CM 2007/ACE:4.

ICES, 2008, Report of the Working Group on Ecosystem Effects of Fishing Activities (WGECO). ICES CM 2008/ACOM:4.

IUCN, 2008, 2008 IUCN Red List of Threatened Species. (http://www.iucnredlist.org)

Johnson D., 2008. Environmental indicators: their utility in meeting the OSPAR Convention's regulatory needs. ICES J. Mar. Sci. 65, $1387-1391$.

Jouanneau J.M., Weber O., Cremer M., Castaing P., 1999, Finegrained sediment budget on the continental margin of the Bay of Biscay. Deep-Sea Res. II, 46, 2205-2220.

Joubin M.L., 1922, Les coraux de mer profonde nuisibles aux chalutiers. Off. Scient. Techn. Pêches Marit. Notes et Mémoires 18, $5-16$.

Kalaydjian R., Daurès F., Gaignon J.-L., Girard S., Guyader O., Matte I., Mongruel R., Pérez J., Thébaud O., 2006, Données économiques maritimes françaises 2005. Ifremer, Brest.

Kirk R.S., 2003, The impact of Anguillicola crassus on European eel. Fish. Manage. Ecol. 10, 385-394.

Koutsikopoulos C., Beillois P., Leroy C., Taillefer F., 1998, Temporal trends and spatial structures of the sea surface temperature in the Bay of Biscay. Oceanol. Acta 21, 335-344.

Labry C., Herbland A., Delmas D., 2002, The role of phosphorus on planktonic production of the Gironde plume waters in the Bay of Biscay. J. Plankton Res. 24, 97-117.

Labry C., Herbland A., Delmas D., Laborde P., Lazure P., Froidefond J.M., Jegou A.M., Sautour B., 2001, Initiation of winter phytoplankton blooms within the Gironde plume waters in the Bay of Biscay. Mar. Ecol. Prog. Ser. 212, 117-130.

Laffargue P., Begout M.L., Lagardère F., 2006, Testing the potential effects of shellfish farming on swimming activity and spatial distribution of sole (Solea solea) in a mesocosm. ICES J. Mar. Sci. 63, 1014-1028. 
Lampert L., Quéguiner B., Labasque T., Pichon A., Lebreton N., 2002, Spatial variability of phytoplankton composition and biomass on the eastern continental shelf of the Bay of Biscay (North-east Atlantic Ocean). Evidence for a bloom of Emiliania huxleyi (Prymnesiophyceae) in spring 1998. Cont. Shelf Res. 22, 1225-1247.

Landry M., 2001, Microbial loops. In: Steele J., Thorpe S., Turekian K., (Eds.) Encyclopedia of Ocean Science, Academic Press, pp. 1763-1770.

Lavin A., Valdés L., Sanchez F., Abaunza P., Forest A., Boucher J., Lazure P., Jégou A.-M., 2005, The Bay of Biscay: the encountering of the ocean and the shelf. In: Robinson A. R., Brink K.H. (Eds.). The global coastal ocean: Interdisciplinary regional studies and syntheses. The sea. Harvard Press, pp. 935-1002.

Le Bris H., Glémarec M., 1995, Macrozoobenthic communities of an oxygen under-saturated coastal ecosystem: the Bay of Vilaine (southern Brittany). Oceanol. Acta 18, 573-581.

Le Danois E., 1948, Les profondeurs de la mer: trente ans de recherches sur la faune sous-marine au large des côtes de France. Payot, Paris.

Le Loc'h F., Hily C., Grall J., 2008, Benthic community and food web structure on the continental shelf of the Bay of Biscay (North Eastern Atlantic) revealed by stable isotopes analysis. J. Mar. Syst. 72, 17-34.

Le Pape O., Guérault D., Desaunay Y., 2004, Effect of an invasive mollusc, American slipper limpet Crepidula fornicata, on habitat suitability for juvenile common sole Solea solea in the Bay of Biscay. Mar. Ecol. Prog. Ser. 277, 107-115.

Le Roux A., 2008, Les espèces introduites dans le MorBihan. Penn Ar Bed 202, 26-36.

Lindeboom H., De Groote S.J., 1998, Environmental impact of bottom gears on benthic fauna in relation to natural resources management and protection of the North Sea. RIVO- DLO, NIOZ Rep. 11, 1994.

Martin J., 2009, Les invertébrés marins du golfe de Gascogne à La Manche orientale. Quae éditions, Versailles.

Massoud Z., Piboubès R., 1994, L'atlas du littoral de France. Paris, Jean-Pierre de Monza.

Maurin H., 1994, Inventaire de la faune menacée en France. MNHN, Nathan, Paris.

Mauvais J.-L., Goarnisson R., 1999, Etat de l'environnement sur la Façade Atlantique. Bilans et perspectives, Ifremer, Brest (http://www.ifremer.fr/docelec/).

Ménesguen A., Aminot A., Belin B., Chapelle A., Guillaud J.-F., Joanny M., Lefebvre A., Merceron M., Piriou J-.Y., Souchu P., 2001, L'eutrophisation des eaux marines et saumâtres en Europe, en particulier en France. IFREMER DEL/EC/01.02. (http://www.ifremer.fr/docelec/)

Ménesguen A., 2003, Les "marées vertes" en Bretagne, la responsabilité du nitrate. Ifremer, Direction de l'environnement et de l'aménagement littoral, Brest (http://www.ifremer.fr/docelec/).

Meuriot E., Grizel H., 1984, Note sur l'impact économique des maladies de l'huître plate en Bretagne. Rapp. Inst. Techn. Inst. Scient. Pêches Marit. 12 (http://www.ifremer.fr/docelec/).

Michel S., Vandermeirsch F, Lorance P., 2009, Evolution of upper layer temperature in the Bay of Biscay during the last 40 years. Aquat. Living Resour. 22, 447-461.

Molnar J.L, Gamboa R.L, Revenga C., Spalding M.D., 2008, Assessing the global threat of invasive species to marine biodiversity. Front. Ecol. Environ. 6, 485-492.

Monperrus M., Point, D., Grall J., Chauvaud L., Amouroux D., Bareille G., Donard O., 2005, Determination of metal and organometal trophic bioaccumulation in the benthic macrofauna of the Adour estuary coastal zone (SW France, Bay of Biscay). J. Environ. Monitor. 7, 693-700.

Morizur Y., Berrow S.D., Tregenza N.J.C., Couperus A.S., Pouvreau S., 1999, Incidental catches of marine mammals in pelagic trawl fisheries of the Northeast Atlantic. Fish. Res. 41, 297-307.

National Research Council, 2003, Oil in the sea. III. Inputs, fates, and effects. National Academy of Sciences, Washington DC.

Olaso I., Velasco F., Pérez N., 1998, Importance of discarded blue whiting (Micromesistius poutassou) in the diet of lesser spotted dogfish (Scyliorhinus canicula) in the Cantabrian Sea. ICES J. Mar. Sci. 55, 331-341.

Oro D., Martinez-Abrain A., 2007, Deconstructing myths on large gulls and their impact on threatened sympatric water seabirds. Anim. Conserv. 10, 117-126.

OSPAR Commission, 2006, Report on North Sea Pilot Project on ecological quality objectives. Biodiversity series 2006/239.

OSPAR Commission, 2000, Quality Status Report 2000: Region IV Bay of Biscay and Iberian Coast. London, OSPAR Commission.

Pascual A., Rodriguez-Lazaro J., Martín-Rubio M., Jouanneau J.M., Weber O., 2008, A survey of the benthic microfauna (Foraminifera, Ostracoda) on the Basque shelf, southern Bay of Biscay. J. Mar. Syst. 72, 35-43.

Péronnet I., 1991, Evaluation des rejets d'espèces commerciales; théorie et application aux pêcheries multispécifiques du golfe de Gascogne et de la mer Celtique. Final Report EC Contract, DG $\mathrm{XIV} / \mathrm{b} / 1: 4930$.

Pitois S.G., Fox C.J., 2006, Long-term changes in zooplankton biomass concentration and mean size over the Northwest European shelf inferred from continuous plankton recorder data. ICES J. Mar. Sci. 63, 785-798.

Planque B., Beillois P., Jégou A.-M., Lazure P., Petitgas P., Puillat, I., 2003, Large-scale hydroclimatic variability in the Bay of Biscay: the 1990s in the context of interdecadal changes. ICES Mar. Sci. Symp. 219, 61-70.

Pons J-M., Migot P., 1995, Life-history strategy of the herring gull: changes in survival and fecundity in a population subjected to various feeding conditions. J. Anim. Ecol. 64, 592-599.

Poulard J.C., Léauté J.P., 2002, Interaction between marine populations and fishing activities: temporal patterns of landings of $\mathrm{La}$ Rochelle trawlers in the Bay of Biscay. Aquat. Living Resour. $15,197-210$.

Poulard J.C., Blanchard F., 2005, The impact of climate change on the fish community structure of the eastern continental shelf of the Bay of Biscay. ICES J. Mar. Sci. 62, 1436-1443.

Poulet S.A., Laabir M., Chaudron Y., 1996, Characteristic features of zooplankton in the Bay of Biscay. Sci. Mar. 60, 79-95.

Quéro J.-C., 1973, Remarques écologiques sur les balistes (Balistes carolinensis, Gmelin, 1789, Pisces, Plectognathi, Balistidae), débarqués à la Rochelle ou capturé aux environs de ce port, de 1959 à 1972. Ann. Soc. Sci. Nat. Charente-Marit. 5, 328-336.

Quéro J.-C., Cendrero O., 1996, Incidence de la pêche sur la biodiversité ichtyologique marine: le bassin d'Arcachon et le plateau continental Sud Gascogne. Cybium 20, 232-356.

Quéro J.C., Dardignac J., Vayne J.-J., 1989, Les poissons du golfe de Gascogne. IFREMER. (http://www.ifremer.fr/docelec/)

Quéro J.C., Du Buit M.H., Fonteneau J., Laborde J.L., Morandeau G., Vayne J.J., 1994, Catch data and new records for the year 1993 in the Atlantic French harbours. Ann. Soc. Sci. Nat. Charente-Marit. 8, 359-369.

Quéro J.C., Du Buit M.H., Vayne J.J., 1998, The records of tropical fishes and the warming of the European Atlantic waters. Oceanol. Acta 21, 345-351. 
Quéro J.-C., Porché P., Vayne J.J., 2003, Guide des poissons de l'Atlantique européen, identifier 955 espèces. Les guides du naturaliste. Delachaux et Niestlé, Lonay, Paris.

RNO, 2000, Surveillance du milieu marin. Travaux du RNO. Edition 2000. Nantes, Ifremer et Ministère de l'Aménagement du Territoire et de l'Environnement.

RNO, 2006, Surveillance du milieu marin. Travaux du réseau national d'observation de la qualité du milieu marin. Edition 2006. Nantes, Ifremer et Ministère de l'Ecologie et du Développement durable.

Robin J.P., 1992, The brown shrimp fishery of the Loire estuary production and bycatch of juvenile fish. Fish. Res. 13, 153-172.

Rochet M.-J., Trenkel V.M., Bellail R., Coppin F., Le Pape O., Mahe J.C., Morin J., Poulard J.C., Schlaich I., Souplet A., Verin Y., Bertrand J., 2005, Combining indicator trends to assess ongoing changes in exploited fish communities: diagnostic of communities off the coasts of France. ICES J. Mar. Sci. 62, 1647-1664.

Rochet M.-J., Bertignac M., Fifas S., Gaudou O., Talidec C., 2006, Estimating discards in the French Nephrops fishery in the Bay of Biscay. ICES 2006/K:24.

Rogan E., Mackey M., 2007, Megafauna bycatch in drift nets for albacore tuna (Thunnus alalunga) in the NE Atlantic. Fish. Res. 86, 6-14.

Rogers A.D., 1999, The biology of Lophelia pertusa (Linnaeus, 1758) and other deep-water reef-forming corals and impacts from human activities. Int. Rev. Hydrobiol. 84, 315-406.
Rohr A.S., Mahan C.G., Kim K.C., 2006, Developing a monitoring program for invertebrates: guidelines and a case study. Conserv. Biol. 2, 422-433.

Sánchez F., Rodríguez-Cabello C., Olaso I., 2005, The role of elasmobranchs in the Cantabrian Sea shelf ecosystem and impact of the fisheries on them. J. Northw. Atl. Fish. Sci. 35, 467-480.

Saulnier D., Reynaud Y., Arzul I., Miossec L., Le Roux L., Goarant C., 2007, Emergence de maladies chez les organismes d'intérêt aquacole: quelques scénarios illustrés d'exemples. INRA Prod. Anim. 20, 207-212.

Sauriau P.-G., Pichoski-Seyfried C., Walker P., de Montaudouin X., Palud C., Héral M., 1998, Crepidula fornicata L. (mollusque gasteropode) en la baie de Marennes-Oléron: cartographie des fonds par sonar à balayage latéral et estimation du stock. Oceanol. Acta 21, 353-362.

Singh R.K., Murty H.R., Gupta S.K., Dikshit A.K., 2009, An overview of sustainability assessment methodologies. Ecol. Indicators 9, 189-212.

Zingone A., Enevoldsen H.O., 2000, The diversity of harmful algal blooms: A challenge for science and management. Ocean Coast. Manage. 43, 725-748.

Zydelis R., Bellebaum J., Osterblom H., Vetemaa M., Schirmeister B., Stipniece A., Dagys M., Van Eerden M., Garthe S., 2009, Bycatch in gillnet fisheries - An overlooked threat to waterbird populations. Biol. Conserv. 142, 7, 1269-1281. 